\title{
Fishes with Eye Shine: Functional Morphology of Guanine Type Tapetum Lucidum
}

\author{
H. Somiya \\ Fisheries Laboratory, Faculty of Agriculture, Nagoya University, Chikusa, Nagoya 464, Japan
}

\begin{abstract}
In several teleost fishes, guanine type ocular tapeta lucida were studied by conventional light and fluorescence microscopy. Retinal tapeta lucida were found in the eyes of Chlorophthalmus albatrossis, Chlorophthalmus nigromarginatus, Chlorophthalmus acutifrons, Beryx splendens, Beryx decadactylus, Polymixia japonica and Polymixia berndti. Choroidal tapeta exist in the eyes of Neoscopelus microchir, Diaphus coeruleus, Diaphus sagamiensis, Epigonus atherinoides, Priacanthus macracanthus, Priacanthus hamrur, Priacanthus boops and Pristigenys niphonia. Spectrophotometric and paper-chromatographic evidence reveals the tapetal material to be mainly guanine. Grouped receptors in the retinas of Chlorophthalmus and Polymixia and argentea in the eyes of Priacanthus are described and a classification of the tapeta lucida in teleosts is given. The relationship between retinal and choroidal tapeta is discussed and a possible explanation offered for the two types of tapetal organization in teleosts. Apparently, the two types are related to the ecology and behavior of the species concerned.
\end{abstract}

\section{INTRODUCTION}

The phenomenon of eye shine has been observed in a variety of animals (Walker, 1939). It is generally related to the presence of a reflecting surface in the eye, i. e. the 'tapetum lucidum' (Walls, 1942; Rochonduvigneaus, 1943; Prince, 1956; Duke-Elder, 1958; Denton and Nicol, 1964; Pirie, 1966; Muntz, 1972). Descriptive studies on tapeta in teleosts began in the middle of the 19th century (Brück, 1845; Müller, 1856; Kühne and Sewall, 1880). After the work of Exner and Januschke (1905), studies were chiefly focussed on guanine tapeta. In recent years, Locket $(1970,1971)$ reported the fine structure of the guanine tapeta in some deep-sea fishes, and Arnott et al. (1970, 1971) documented lipid tapeta in some teleosts. These reports stimulated studies on the teleost tapetum and led to the electron microscopic and biochemical studies which discovered several new chemical type tapeta (Nicol, 1975, and Lockęt, 1977). In the Teleostei, two types of tapeta, retinal and choroidal, can be distinguished morphologically.

Although considerable attention has been paid to teleost tapeta lucida in recent years, comparatively little is known of teleost choroidal tapeta, and nothing is known of the relationship between retinal and choroidal tapeta. During the last years, the author investigated the vision of several fishes. Guanine tapeta, responsible for conspicuous eye shine, were found in 15 species. Chlorophthalmus and Polymixia have a grouped receptor retina related to a guanine tapetum.
The present paper describes the histological structures of the guanine tapeta lucida and the grouped receptor retina in some teleosts. The argentea in Priacanthus eyes is also described in relation to the structure of the choroidal tapeta. That the reflecting material of these tapeta is mainly guanine was demonstrated by chemical analysis. A classification of teleost tapeta was made in order to consider some aspects of tapetal organization. Especially the relationship between retinal and choroidal tapeta is discussed and a hypothesis presented, which attempts to explain tapetal organization in ecological terms.

\section{MATERIALS AND METHODS}

The 70 species examined in the present study are listed in Table 1. These species were obtained from many different places. The fishes are divided into three groups. The first group comprises coastal species (A); the second, deep-sea species (B) collected from Kumano-nada (the Sea of Kumano, Mie prefecture, Japan); the third, oceanic or micronektonic deep-sea species (C), collected during the $\mathrm{KH}-72-1$ cruise of the Sea of South East Asia by R. V. Hakuho-Maru, Ocean Research Institute, University of Tokyo (Japan).

In most fishes a small hand lamp was used to examine eye shine. Eyes for histological study were fixed in Bouin's fluid. Serial sections of $8 \mu \mathrm{m}$ thickness were made and stained with Mayer's acid-haemalum and eosin. These sections were examined by conventional light and fluorescence microscopy. The tapetal 
Table 1. Fish species examined in the present study

\begin{tabular}{|c|c|c|c|}
\hline Order, family & Species & $\begin{array}{l}\text { Strong } \\
\text { eye shine }\end{array}$ & Habitat \\
\hline \multicolumn{4}{|l|}{ Clupeiformes } \\
\hline \multirow[t]{10}{*}{ Gonostomatidae } & Diplophos orientalis Matsubara & - & $\mathrm{C}$ \\
\hline & Gonostoma gracile Günther & - & $\mathrm{C}$ \\
\hline & Cyclothone alba Brauer & - & $\mathrm{C}$ \\
\hline & Cyclothone pseudopallida Mukhacheva & - & C \\
\hline & Cyclothone pallida Brauer & - & $\mathrm{C}$ \\
\hline & Cyclothone atraria Gilbert & - & $\mathrm{C}$ \\
\hline & Cyclothone acclinidens Garman & - & C \\
\hline & Cyclothone obscura Braver & - & $\mathrm{C}$ \\
\hline & Ichthyococcus elongatus Imai & - & $\mathrm{C}$ \\
\hline & Maurolicus muelleri (Gmelin) & - & $\mathrm{C}$ \\
\hline \multirow[t]{3}{*}{ Sternoptychidae } & Argyтopelecus affinis Garman & - & $\mathrm{C}$ \\
\hline & Argyropelecus sladeni Regan & - & $\mathrm{C}$ \\
\hline & Sternoptyx diaphana Hermann & - & C \\
\hline \multicolumn{4}{|l|}{ Myctophiformes } \\
\hline Aulopodidae & Hime japonica (Günther) & - & B \\
\hline \multirow[t]{3}{*}{ Chlorophthalmidae } & Chlorophthalmus nigromarginatus Kamohara & + & B \\
\hline & ChIorophthalmus albatrossis Jordan et Starks & + & $B$ \\
\hline & Chlorophthalmus acutifrons Hiyama & + & $\mathrm{B}$ \\
\hline \multirow[t]{3}{*}{ Myctophidae } & Neoscopelus microchir Matsubara & + & B \\
\hline & Diaphus coeruleus Klunzinger & + & $\mathrm{B}$ \\
\hline & Diaphus sagamiensis Gilbert & + & B \\
\hline \multicolumn{4}{|l|}{ Syngnathiformes } \\
\hline Macrorhamphosidae & Macrorhamphosus scolopax (L.) & - & $\mathrm{B}$ \\
\hline \multicolumn{4}{|l|}{ Beryciformes } \\
\hline \multirow[t]{2}{*}{ Berycidae } & Beryx splendens Lowe & + & $\mathrm{B}$ \\
\hline & Beryx decadactylus Cuvier et Valenciennes & + & $\mathrm{B}$ \\
\hline \multirow[t]{2}{*}{ Polymixidae } & Polymixia japonica Günther & + & $\mathrm{B}$ \\
\hline & Polymixia berndti Gilbert & + & $\mathrm{B}$ \\
\hline \multicolumn{4}{|l|}{ Perciformes } \\
\hline \multirow[t]{2}{*}{ Mugilidae } & Mugil cephalus L. & - & A \\
\hline & Liza haematocheila (Temminck et Schlegel) & - & A \\
\hline \multirow[t]{3}{*}{ Scombridae } & Euthynnus pelamis (L.) & - & A \\
\hline & Auxis thazard (Lacepède) & - & A \\
\hline & Auxis rochei (Risso) & - & A \\
\hline Coryphaenidae & Coryphaena hippurus L. & - & A \\
\hline Carangidae & Seriola quinqueradiata Temminck et Schlegel & - & A \\
\hline \multirow[t]{2}{*}{ Oplegnathidae } & Oplegnathus fasciatus (Temminck et Schlegel) & - & $A$ \\
\hline & Oplegnathus punctatus (Temminck et Schlegel) & - & A \\
\hline Apogonidae & Epigonus atherinoides (Gilbert) & + & $\mathrm{B}$ \\
\hline \multirow[t]{4}{*}{ Priacanthidae } & Priacanthus macracanthus Cuvier & + & A, B \\
\hline & Priacanthus hamrur (Forsskảl) & + & $A, B$ \\
\hline & Priacanthus boops (Bloch et Schneider) & + & A, B \\
\hline & Pristigenys niphonia (Cuvier) & + & A, B \\
\hline \multirow[t]{4}{*}{ Serranidae } & Lateolabrax japonicus (Cuvier) & - & A \\
\hline & Epinephelus akaara (Temminck et Schlegel) & - & A \\
\hline & Epinephelus septemfasciatus (Thunberg) & - & A. \\
\hline & Epinephelus fasciatus (Forsskål) & - & A \\
\hline Sillaginidae & Sillago japonica Temminck et Schlegel & - & A \\
\hline Girellidae & Girella punctata Gray & - & A \\
\hline \multirow[t]{3}{*}{ Sparidae } & Evynnis japonica Tanaka & - & $\mathrm{A}$ \\
\hline & Acanthopagrus schlegelii (Bleeker) & - & A \\
\hline & Pagrus major (Temminck et Schlegel) & - & A \\
\hline Pomadasyidae & Parapristipoma trilineatum (Thunberg) & - & A \\
\hline Aplodactylidae & Goniistius zonatus (Cuvier et Valenciennes) & - & A \\
\hline & Goniistius zebra (Döderlein) & - & A \\
\hline Parapercidae & Neopercis sexfasciata (Temminck et Schlegel) & - & A \\
\hline Embiotocidae & Ditrema temmincki Bleeker & - & $A$ \\
\hline Labridae & Choerodon azurio (Jordan et Snyder) & - & A \\
\hline & Bodianus hirsutus (Lacepède) & - & A \\
\hline
\end{tabular}


Table 1 (continued). Fish species examined in the present study

\begin{tabular}{|c|c|c|c|}
\hline Order, family & Species & $\begin{array}{l}\text { Strong } \\
\text { eye shine }\end{array}$ & Habitat \\
\hline & Pseudolabrus japonicus (Houttuyn) & - & A \\
\hline & Halichoeres poecileptenus (Temminck et Schlegel) & - & A \\
\hline Scorpididae & Microcanthus strigatus (Cuvier et Valenciennes) & - & A \\
\hline Caetodontidae & Chaetodon nippon Steindachner et Döderlein & - & A \\
\hline Acanthuridae & Prionurus microlepidotus Lacepède & - & A \\
\hline \multicolumn{4}{|l|}{ Tetraodontiformes } \\
\hline \multirow[t]{2}{*}{ Aluteridae } & Stephanolepis cirrhifer (Temminck et Schlegel) & - & A \\
\hline & Novodon modestus (Günther) & - & A \\
\hline \multirow[t]{3}{*}{ Tetraodontidae } & Fugu rubripes chinensis (Abe) & - & A \\
\hline & Fugu vermicularis vermicularis (Temminck et Schlegel) & - & A \\
\hline & Fugu pardalis (Temminck et Schlegel) & - & A \\
\hline \multicolumn{4}{|l|}{ Cottiformes } \\
\hline \multirow[t]{3}{*}{ Scorpaenidae } & Sebastes inermis Cuvier & - & A \\
\hline & Sebastes joyneri Günther & - & A \\
\hline & Sebastiscus marmoratus (Cuvier) & - & A \\
\hline Xexagrammidae & Agrammus agrammus (Temminck et Schlegel) & - & A \\
\hline Pleuronectiformes & & & \\
\hline Pleuronectidae & Limanda yokohamae (Günther) & - & A \\
\hline
\end{tabular}

material (guanine) shows strong fluorescence. In several fishes, frozen material was kept for an assay of the reflecting substances of the tapeta and argentea.

To identify the reflecting materials, spectrophotometrical and paper-chromatographical studies were performed. These techniques were essentially the same as those described by Nicol and Van Baalen (1968), and Zyznar and Nicol (1973).

\section{Spectrophotometry}

Extraction of reflecting substances in the tapeta was carried out as follows. The deep-frozen eyes were defrosted at room temperature and the cornea, lens and most of the transparent neural retina were removed. The remaining reflecting material was then sucked directly into a hypodermic syringe, care being taken to avoid contamination by the argentea of the suprachoroid. The tapetal material, taken from the eye cup, was then washed three times with distilled water and dissolved in $0.1 \mathrm{~N} \mathrm{NaOH}$. This solution was centrifuged and the supernatant taken for analysis. The same procedure was applied for making the extracts of reflecting substances in the argentea of choroid and iris.

To identify the reflecting substance of tapeta and argentea, the ultraviolet (UV) absorption spectrum of the tapetal extract in three solvents, i. e. $\mathrm{HCl}$, Tris hydroxymethyl aminomethane buffer ( $\mathrm{pH}$ 7), $\mathrm{NaOH}$ was measured by a Hitachi recording spectrophotometer, and compared with the absorption spectrum of authentic guanine. Guanine contents of tapeta were estimated by the differential extinction technique (Bendich, 1957).

\section{Paper-Chromatography}

The tapetal extract $(0.1 \mathrm{~N} \mathrm{NaOH}$ or $0.1 \mathrm{~N} \mathrm{HCl})$ of Chlorophthalmus albatrossis was chromatographed ascendingly on a filter paper (Toyo Roshi No. 51-A) at room temperature. Uric acid, inosine, guanosine, guanine, hypoxanthine and xanthine were used as controls along with the tapetal sample. Three kinds of solvent systems were used. The chromatograms were examined with light from a short wavelength emitting UV lamp.

\section{RESULTS}

\section{Eye Shine}

Among the fishes examined, 15 species show strong eye shine (Tables 1,2 ). They exhibit less remarkable eye shine in ordinary scattering light (Fig. 1A; Beryx splendens). The eye colour of chlorophthalmid fish is green, but they show strong eye shine when illuminated by flash gun (Fig. 1B-F).

\section{Histology of Tapeta Lucida}

The eye cups of the species with strong eye shine were examined histologically. This examination 
revealed tapeta lucida. Morphologically, two tapeta types, retinal and choroidal, were observed in these eyes (Table 2). For each genus brief descriptions of the tapeta are presented. To clarify the structural and positional difference between the two types of tapeta, their histology was studied by light and fluorescence microscopy.

\section{Retinal Tapeta}

A tapetum located in the retinal pigment epithelium occurs in the eyes of Chlorophthalmus, Beryx and Polymixia. In the retina of Chlorophthalmus and Polymixia, also grouped receptors are present.

The retina of Beryx decadactylus (Fig. 2A) and Beryx splendens (Fig. 2B) exhibits the same histological features. They possess large eyes with a pure rod retina. The pigment epithelium is moderately reduced, but contains tapetal material recognized to be guanine and melanine granules.

Chlorophthalmus albatrossis (Figs 2C, 3A-C), Chlorophthalmus nigromarginatus and Chlorophthalmus acutifrons exhibit the same histological features of their retina. The histological features of the retina of $C$. albatrossis have been described previously (Tamura, 1957; Somiya and Tamura, 1971; Somiya, 1977). In the present study, specializations of the retinal tapeta were observed. The retina contains populations of cones (only twin cones) and rods. The retina is divided into two parts, a twin cone area and a rod area. The former, where the visual cells are all twin cones, is located in the ventral region of the eye cup. The rest of the retina is occupied by rods, which are aggregated into bundles (grouped receptors). The grouped rod area is further divided into two parts, one consisting of linear, and the other of round (spot-like) rod bundles as a result of the

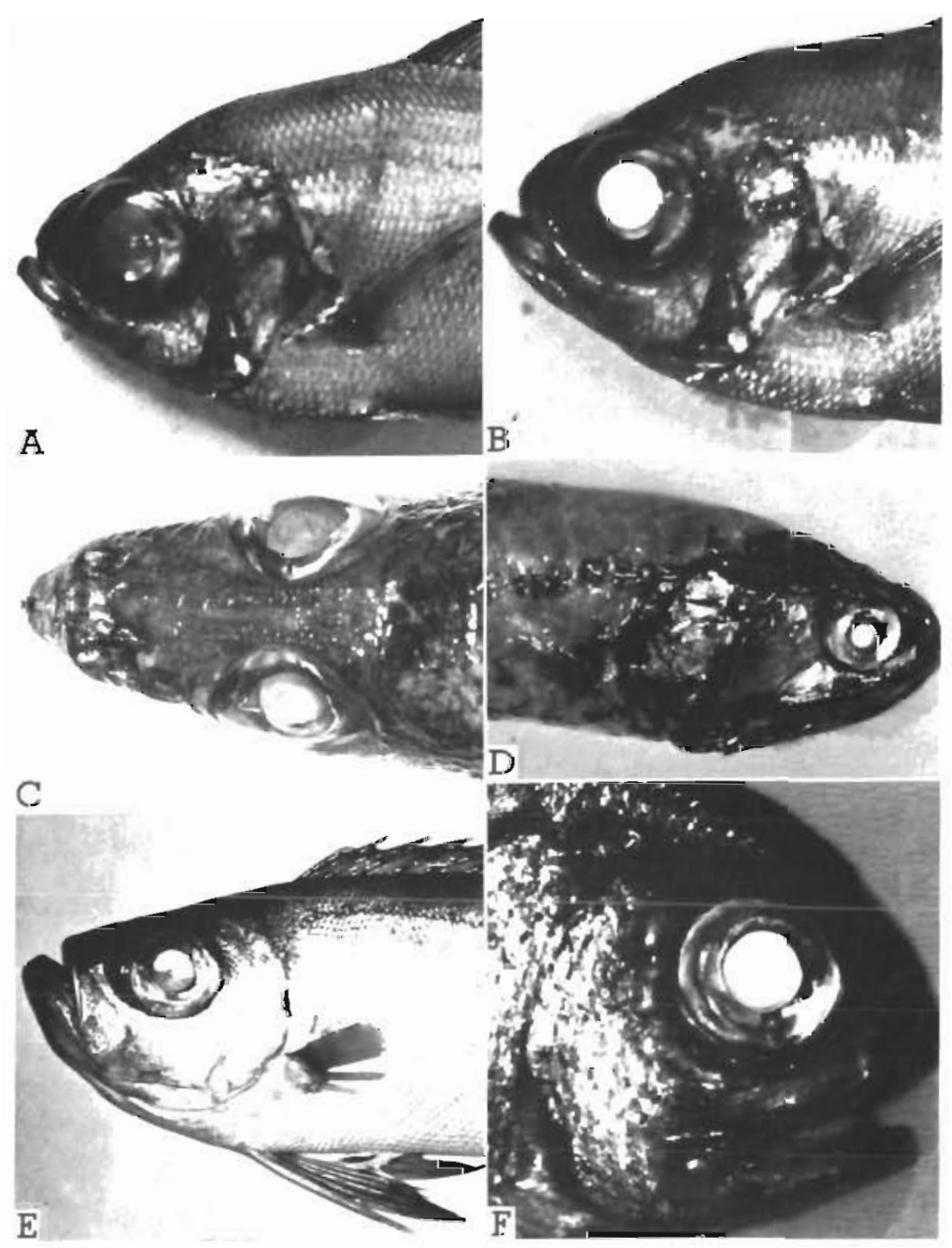

Fig. 1. Eye shine of fishes. A: Beryx splendens, standard length (SL) $=35 \mathrm{~cm}$. B: Beryx splendens, showing strong eye shine when photographed by using a flash gun. C: Chlorophthalmus nigromarginatus, $\mathrm{SL}=25 \mathrm{~cm}$. D: Diaphus coeruleus, SL $=15 \mathrm{~cm}$. E: Priacanthus macracanthus, SL $=30 \mathrm{~cm}$. F: Polymixia japonica, $\mathrm{SL}=30 \mathrm{~cm}$ 
Table 2. Fishes with strong eye shine and guanine tapeta lucida

\begin{tabular}{|c|c|c|c|c|}
\hline Family, species & $\begin{array}{l}\text { Colour of } \\
\text { eye shine }\end{array}$ & $\begin{array}{l}\text { Morphological } \\
\text { type of tapeta }\end{array}$ & Visual cell & $\begin{array}{l}\text { Detection of guanine } \\
\text { (Method) }\end{array}$ \\
\hline \multicolumn{5}{|l|}{ Chlorophthalmidae } \\
\hline Chlorophthalmus nigromarginatus & yellowish & $\mathrm{RT}+\mathrm{G}$ & $t c+r$ & fluorescence microscopy \\
\hline C. albatrossis & yellowish & $\mathrm{RT}+\mathrm{G}$ & tc $+r$ & spectrophotometry, chromatography \\
\hline C. acutifrons & yellowish & $R T+G$ & tc $+r$ & fluorescence microscopy \\
\hline \multicolumn{5}{|l|}{ Myctophidae } \\
\hline Neoscopelus microchir & yellowish & $\mathrm{CT}$ & rod retina & fluorescence microscopy \\
\hline Diaphus coeruleus & bluish & $\mathrm{CT}$ & rod retina & spectrophotometry \\
\hline D. sagamiensis & bluish & $\mathrm{CT}$ & rod retina & spectrophotometry \\
\hline \multicolumn{5}{|l|}{ Berycidae } \\
\hline Beryx splendens & yellow white & RT & rod retina & spectrophotometry \\
\hline B. decadactylus & yellow white & $\mathrm{RT}$ & rod retina & fluorescence microscopy \\
\hline \multicolumn{5}{|l|}{ Polymixiidae } \\
\hline Polymixia japonica & yellow white & $\mathrm{RT}+\mathrm{G}$ & rod retina & spectrophotometry \\
\hline P. berndti & yellow white & $\mathrm{RT}+\mathrm{G}$ & rod retina & fluorescence microscopy \\
\hline \multicolumn{5}{|l|}{ Apogonidae } \\
\hline Epigonus atherinoides & yellowish & $\mathrm{CT}$ & rod retina & fluorescence microscopy \\
\hline \multicolumn{5}{|l|}{ Priacanthidae } \\
\hline Priacanthus macracanthus & yellowish & $\mathrm{CT}$ & $t_{c}, s c+r$ & spectrophotometry \\
\hline P. hamrur & yellowish & $\mathrm{CT}$ & tc, sc $+r$ & spectrophotometry \\
\hline P. boops & yellowish & $\mathrm{CT}$ & tc, $s c+r$ & spectrophotometry \\
\hline Pristigenys niphonia & yellowish & $\mathrm{CT}$ & tc, $s \mathrm{c}+\mathrm{r}$ & fluorescence microscopy \\
\hline
\end{tabular}

bundle form of tangential sections at the photoreceptor layer levels (Fig. 3B, C). Figure 4A displays in tangential sections. The lines shown correspond to linear rod bundles which are arranged vertically in the nasal and temporal portions of the retina. Inwardly from the nasal and temporal parts of the retina a transition from linear rod bundles into round bundles can be seen. The latter are indicated by dots. These rod bundles are regularly separated by the processes of pigment epithelial cells which contain guanine reflectors. The pigment epithelial cells of the rod area appear to contain more guanine than those of the twin cone area as shown by the intensity of fluorescence (Figs $2 \mathrm{C}$ and $3 \mathrm{~A}$ ).

The retina of Polymixia japonica (Fig. 5A-D) and Polymixia berndti contain only rods, and have a welldeveloped pigment epithelium comprising dense concentrations of guanine and melanine. Rods are distributed in bundles throughout the whole retina (grouped receptor retina). In this grouped retina of Polymixia, rods in small bundles form round shapes in tangential sections at the photoreceptor layer levels (Fig. 4B, C). In the small nasal and temporal margin of the retina a few shorter linear rod bundles were also observed (Fig. 5D).

\section{Choroidal Tapeta}

This tapetum type is situated in the vitread region of the choroid; in the material examined, it consists of a few layers of reflecting cells. Such a tapetum was observed in the eyes of Diaphus, Neoscopelus, Epigonus, Priacanthus and Pristigenys.

The retina of Diaphus coeruleus (Fig. 6A) reveals the same histological features as does Diaphus sagamiensis. The retina is of a pure rod type and features a tapetum between choriocapillaries and visual cell layer. The pigment epithelial cells are extremely thin and contain no (or little) melanine. The retina of Neoscopelus microchir (Fig. 6B) contains only rods. The tapetal reflector is in the vitread region of the choroid. Blood cells (possibly in a capillary vessel) occur between the tapetal reflector and the visual cell layer.

Epigonus atherinoides (Fig. 7A) has also a pure rod retina. The tapetal reflector is observed in the vitread region of the choroid. Blood cells occur between tapetum and visual cell layer (Fig. 7A3). The retina of Priacanthus macracanthus has the same histological features as that of Priacanthus boops (Fig. 7B) and Priacanthus hamrur. The retina is duplex; cones (single and twin) and rods are observed. The position of the tapetal reflector is the same as that of Neoscopelus and Epigonus. Blood cells occur between tapetal reflector and reduced pigment epithelial cells (Fig. 7B3). The histological features of the retina of Pristigenys niphonia are essentially the same as those of Priacanthus. The retina is duplex (cones and rods), and the tapetal reflector occurs in the vitread region of the choroid. Blood cells were found between tapetum and visual cell layer. 


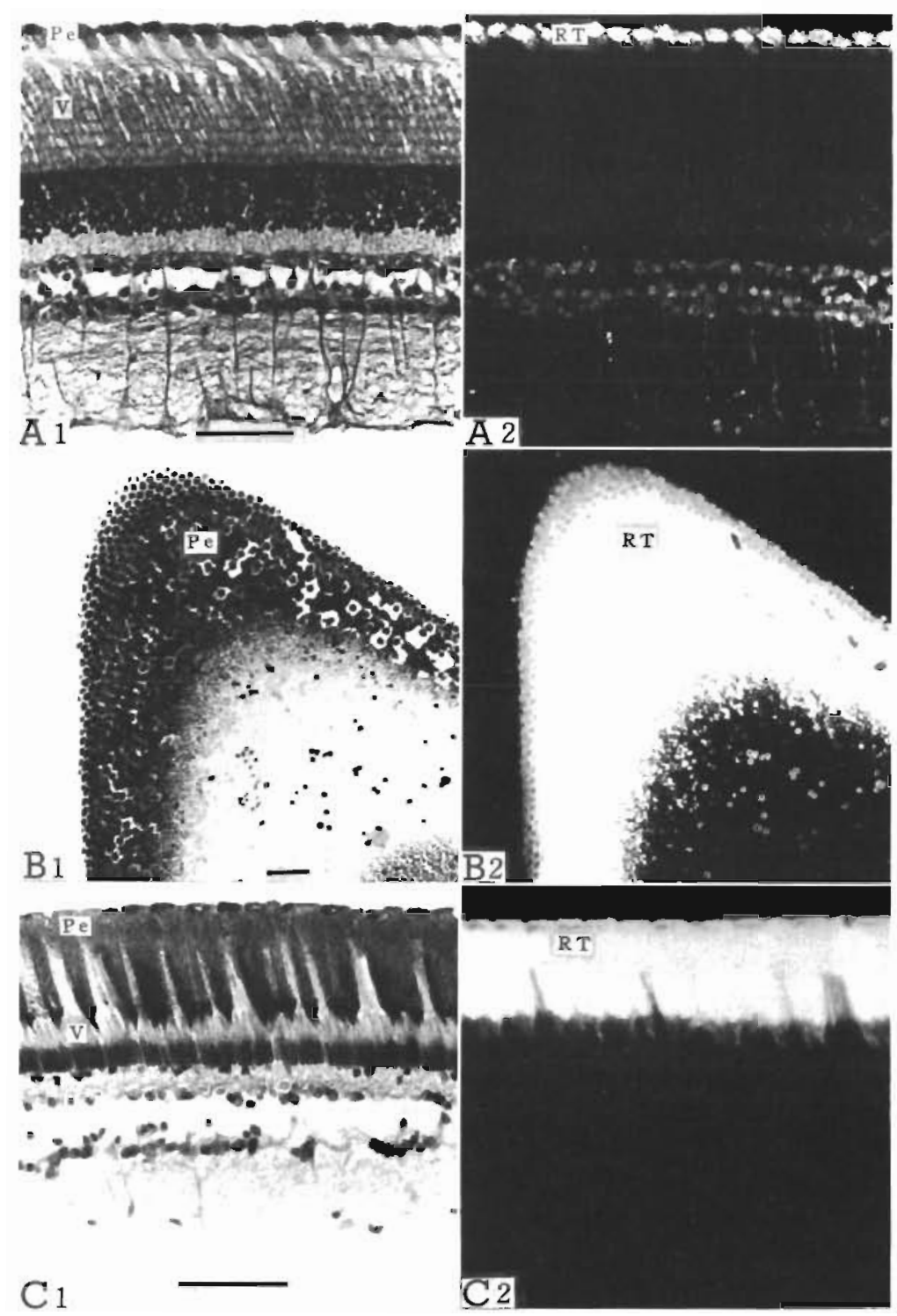

Fig. 2. Histological structures of retinal tapetum. $A_{1}-C_{1}$ : light; $A_{2}-C_{2}$ : fluorescence microscopy, bar $=50$ um. A: Beryx decadactylus; cross section of pure rod retina. B: Beryx splendens; tangential section of pure rod retina. C: Chlorophthalmus albatrossis; cross section of rod area showing fluorescence of pigment epithelium (Pe). Pe: pigment epithelium; RT: retinal tapetum; $\mathrm{V}$ : visual cell layer

The histological features of the two types of guanine tapetum are illustrated diagrammatically in Figure 8. The retinal tapetum is formed in the pigment epithelial cells which contain dense concentrations of guanine reflectors. The pigment epithelial cells also contain melanine. Movements of the two types of inclusion may occur as part of the retinomotor responses to light and dark adaptation. The choroidal tapetum is located in the vitread region of the choroid, and in most cases the crystal arrangement is such that it forms a specular reflector. In many retinas with a choroidal tapetum, the retinal pigment epithelial cells are extremely reduced in size and number, and usually contain no melanine.
Such a reduced epithelium cannot take part in retinomotor response. In the present study, the guanine tapeta may all be classified as retinal or choroidal types; however, the possible existence of intermediate tapeta types should not be ruled out.

\section{Argentea in the Eyes of Priacanthus boops}

An argentea is a guanine-containing reflecting layer commonly found in the sclerad region of the choroid and iris in teleosts. Histologically, the argentea is composed of choroidal guanophores (often called 


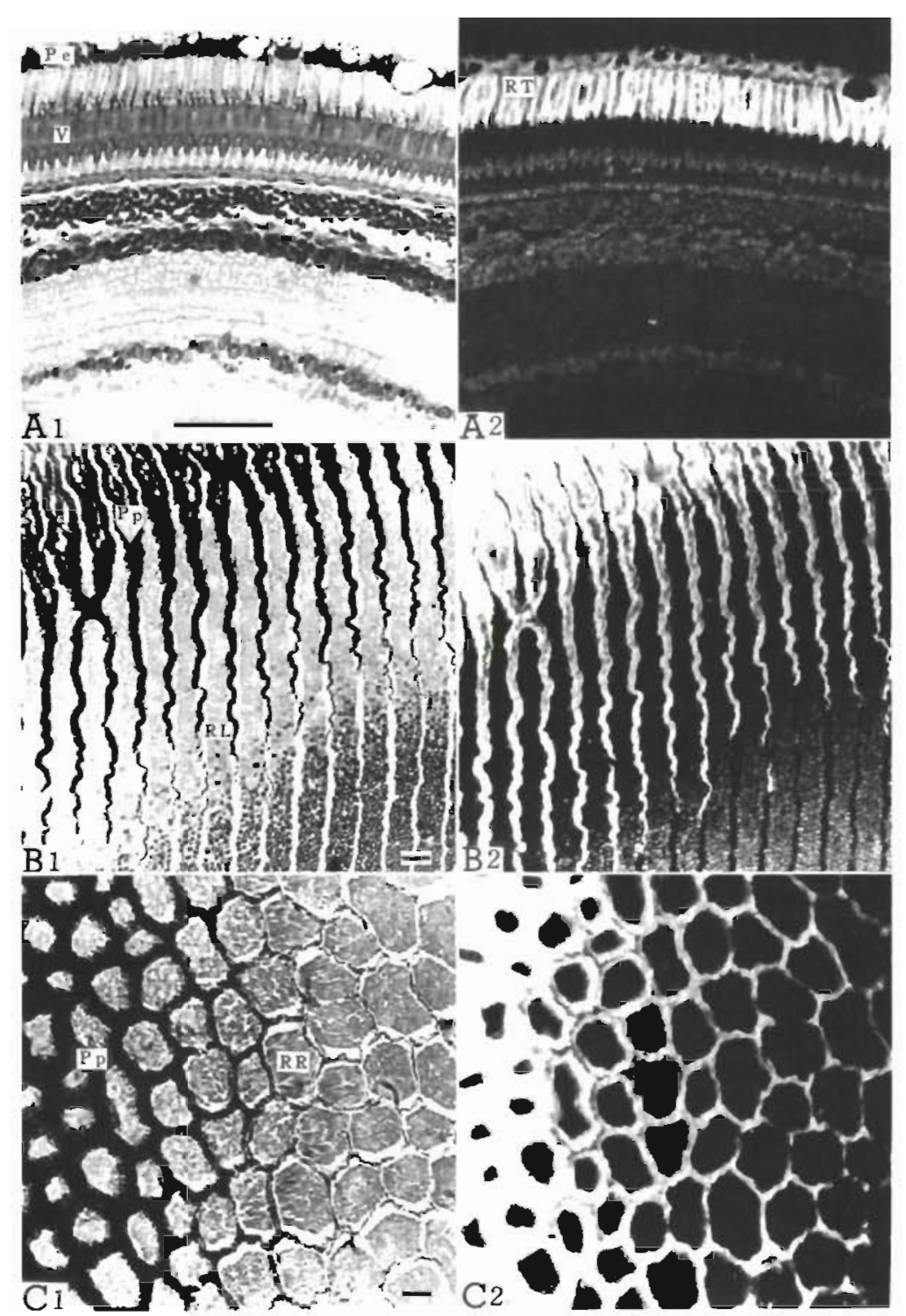

Fig. 3. Chlorophthalmus albatrossis. Histological structures of retinal tapetum. $A_{1}-C_{1}$ : light; $A_{2}-C_{2}$ : fluorescence microscopy, $A$ : cross section of twin cone area, bar $=50 \mu \mathrm{m}$. B-C: tangential section of rod area, bar $=10 \mu \mathrm{m}$. Pe: pigment epithelium; Pp process of pigment epithelium; RL: linear rod bundle; RR: round rod bundle; RT: retinal tapetum; V: visual cell layer

iridophores or iridocytes; Kunz and Wise, 1977). The argentea covers the uveal coat, thus extending over the sclerad surface of both choroid and iris (Fig. 9). Histologically, argentea and the choroidal tapetum have much the same appearance (Fig. 7B). Argentea and choroidal tapetum are situated in the outer (sclerad) and the inner (vitread) parts of the choroid, respectively (Figs. 7B and 9A).

In the retinal part of the iris of Priacanthus boops, the pigment epithelium of the iris (stratum pigmenti iridis) continues to the retinal pigment epithelium (stratum pigmenti retinae) (Fig. 9A, B). This pigment layer contains melanine in this iris part, but gradually loses melanine in the part of ora serrata and contains no melanine in the part of the retina. In the remainder of the iris of $P$. boops, two pigmented elements are observed (Fig. 9B). One is the melanophore layer (the inner region), the other the argentea of the iris (the outer region). These two pigment layers continue to the choroid, thus forming three layers, i. e. an argentea of choroid (the outer region), a melanophore layer (the intermediate region) and a choroidal tapetum (the inner region) (Figs $7 \mathrm{~B}$ and 9A, B). The present observation of histological similarities and positional relationship between argentea and tapetum suggests that the choroidal tapetum is also one component of the guanine containing reflecting layer in the eye, that is, an inner 'branch' of choroid argentea. 


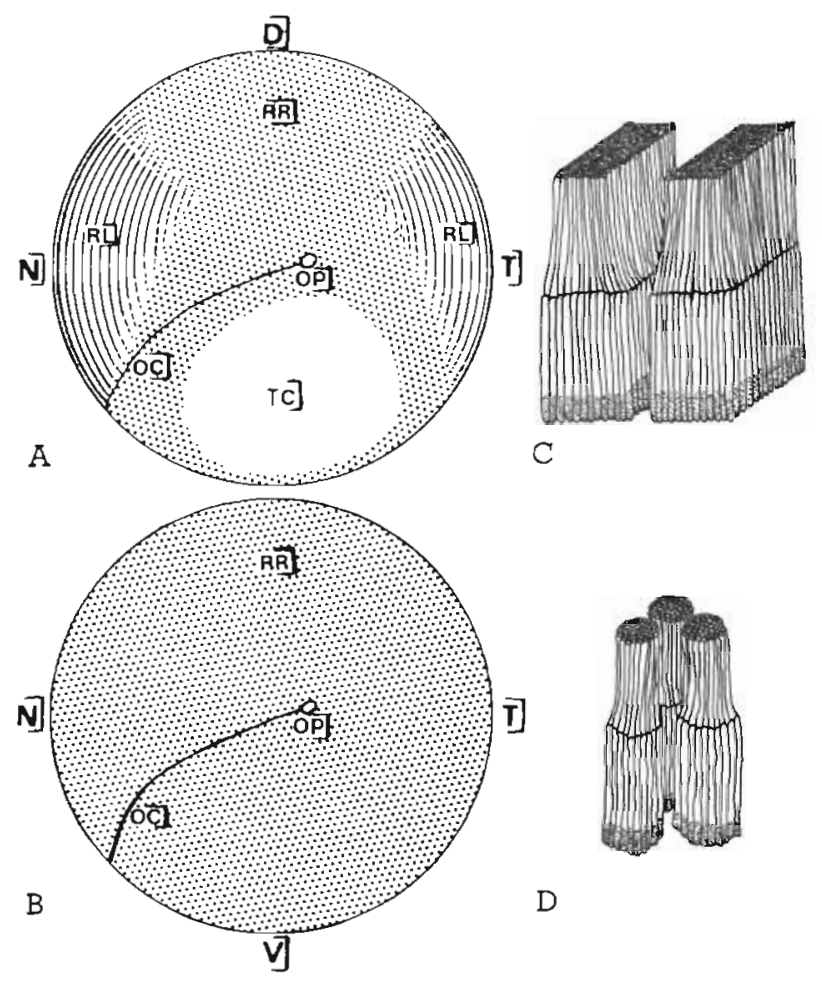

Fig. 4. A, B: schematic representation of retinal eye cup of Chlorophthalmus albatrossis (A) and Polymixia japonia (B), showing the peculiar visual cell arrangements. D: dorsal; $N$ : nasal; $\mathrm{T}$ : temporal; $\mathrm{V}$; ventral. $\mathrm{C}, \mathrm{D}$ : three-dimensional figures of two typical rad bundles, linear rod bundles (C) and round rod bundles (D). OC: optic cleft; OP: optic papilla; RL: linear rod bundle; RR: round rod bundle; TC: twin cone area

\section{Biochemical Identification of Tapetal Materials}

Spectrophotometry

Ultraviolet absorption (UV) spectra of the authentic guanine (Fig. 10-1) and tapetal extract from Chlorophthalmus albatrossis (Fig. 10-2), in three solvents, were measured and compared with each other. UV spectra of the extracts of retinal and choroidal tapeta of several species are shown in Figures 11 and 12, respectively. These figures show that the spectra of the tapetal extracts are the same as those of the authentic guanine

Table 3. Amounts of guanine in tapeta lucida

\begin{tabular}{|lccc|}
\hline \multicolumn{1}{|c}{ Species } & $\begin{array}{c}\text { SL } \\
(\mathrm{cm})\end{array}$ & $\begin{array}{c}\mathrm{mg} \\
\mathrm{eye}^{-1}\end{array}$ & $\begin{array}{c}\mathrm{mg} \\
\mathrm{cm}^{-2}\end{array}$ \\
\hline Chlorophthalmus albatrossis & 15 & $3.01^{\circ}$ & 2.6 \\
Polymixia japonica & 16 & $18.70^{\circ}$ & 10.5 \\
Diaphus coeruleus & 12 & $0.07^{\cdot}$ & 0.1 \\
Beryx splendens & 26 & - & $0.01^{*}$ \\
& & & \\
- Measured value; SL: standard length. & & \\
\hline
\end{tabular}

and that these tapetal materials are thus guanine. UV spectra of the extracts of argentia in choroid and iris were examined in several species (Fig. 13). This figure also indicates that the chief component of these reflecting materials in the argentia of choroid and iris is guanine.

By using the differential extinction technique, guanine contents of the tapeta were calculated (Table 3). The largest amount of guanine occurs in the retinal tapeta of Polymixia japonica (10.5 $\mathrm{mg} \mathrm{cm}^{-2}$ ). The results are coincident with the intensity of fluorescence witnessed by fluorescence microscopy.

\section{Paper-Chromatography}

The tapetal extracts from Chlorophthalmus albatrossis moved at the same rate on paper as authentic guanine in 3 solvent systems. But xanthine, hypoxanthine, guanosine, inosine and uric acid were not detected by this method (Table 4).

\section{DISCUSSION}

\section{Classification of Tapeta Lucida in Teleostei}

At present, tapeta lucida in teleosts can be classified by two criteria, morphological and chemical (Table 5). Morphologically, two types of tapetum are identifiable: the retinal tapetum lucidum and the choroidal tapetum. Retinal tapeta are subdividable into two types based on visual cell arrangement, i. e. nongrouped (normal) and grouped receptor types. Chemically, retinal tapeta are classifiable into several types, depending on the chemical nature of their reflecting materials. At least five quite distinct substances have been reported as tapetal materials, i. e. guanine, uric acid, lipid (glyceryl tridocosahexaenoate), pteridine (7,8-dihydroxanthopterin) and melanoid (a tetramer of 5,6-dihydroxyindole-2-carboxylic acid combined with decarboxylated S-adenosylmethionine) (Arnott et al., 1971; Nicol et al., 1972; Zyznar and Nicol, 1973; Ito and Nicol, 1974; Ito et al., 1975; Nicol et al., 1975; Zyznar and Ali, 1975; Ito and Nicol, 1976; Zyznar et al., 1978). On the other hand, the reflecting material of choroidal tapeta is simply guanine (Nicol and Zyznar, 1973; present study).

All teleosts, known to the author, which possess guanine tapeta are listed in Table 6. Members of 16 families possess guanine tapeta. But chemical reexamination of the tapetal materials seems to be neces- 
Table 4. Chlorophthalmus albatrossis. Rf values for tapetal extract and for purine and nucleoside

\begin{tabular}{|c|c|c|c|c|c|c|c|c|c|}
\hline Solvent system & $\begin{array}{l}\text { Tapetal } \\
\text { extract } \\
\text { in } \mathrm{HCl}\end{array}$ & $\begin{array}{c}\text { Guanine } \\
\text { in } \mathrm{HCl}\end{array}$ & $\begin{array}{c}\text { Tapetal } \\
\text { extract } \\
\text { in } \mathrm{NaOH}\end{array}$ & $\begin{array}{l}\text { Guanine } \\
\text { in } \mathrm{NaOH}\end{array}$ & $\begin{array}{l}\text { Xan- } \\
\text { thine }\end{array}$ & $\begin{array}{c}\text { Hypo- } \\
\text { xan- } \\
\text { thine }\end{array}$ & $\begin{array}{l}\text { Guano- } \\
\text { sine }\end{array}$ & Inosine & $\begin{array}{l}\text { Uric } \\
\text { acid }\end{array}$ \\
\hline $\begin{array}{l}\text { n-Butanol: acetic acid: } \\
\text { water }\{4: 1: 1)\end{array}$ & 0.21 & 0.21 & 0.31 & 0.31 & 0.28 & 0.39 & 0.23 & 0.24 & 0.19 \\
\hline $\begin{array}{l}\text { water saturated n-Butanol } \\
\text { formic acid }(1.1)\end{array}$ & 0.57 & 0.58 & 0.66 & 0.66 & 0.62 & 0.72 & 0.66 & 0.66 & 0.46 \\
\hline $\begin{array}{l}5 \% \mathrm{Na}_{2} \mathrm{HPO}_{4}: \text { isoamyl } \\
\text { alcohol }(1: 1)\end{array}$ & 0.44 & 0.44 & 0.45 & 0.45 & 0.51 & 0.63 & 0.67 & 0.78 & 0.40 \\
\hline
\end{tabular}

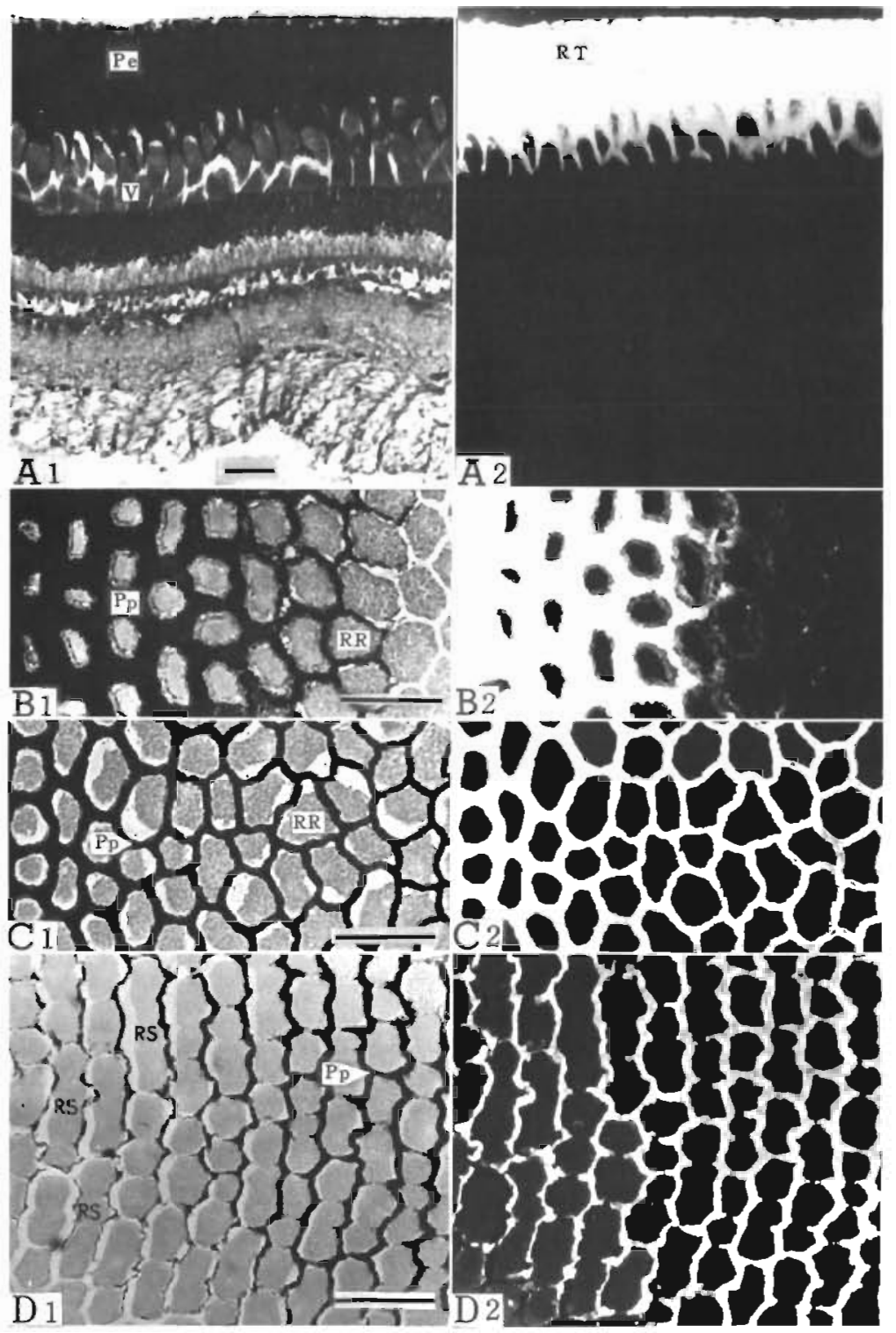

Fig. 5. Polymixia japonica. Histological structures of retinal tapetum, bar $=50 \mu \mathrm{m} . \mathrm{A}_{1}-\mathrm{D}_{1}$ : light; $\mathrm{A}_{2}-\mathrm{D}_{2}$ : fluorescence microscopy A: cross section of retina. B-D: tangential section of retina. B, C: dorsal and temporal parts of the retina. D: a few short linear rod bundles (RS) observed in temporal (or nasal) margins of retina. Pe: pigment epithelium; Pp: process of pigment epithelium; RR: round rod bundle; RS: short linear rod bundle; RT: retinal tapetum; V: visual cell layer 


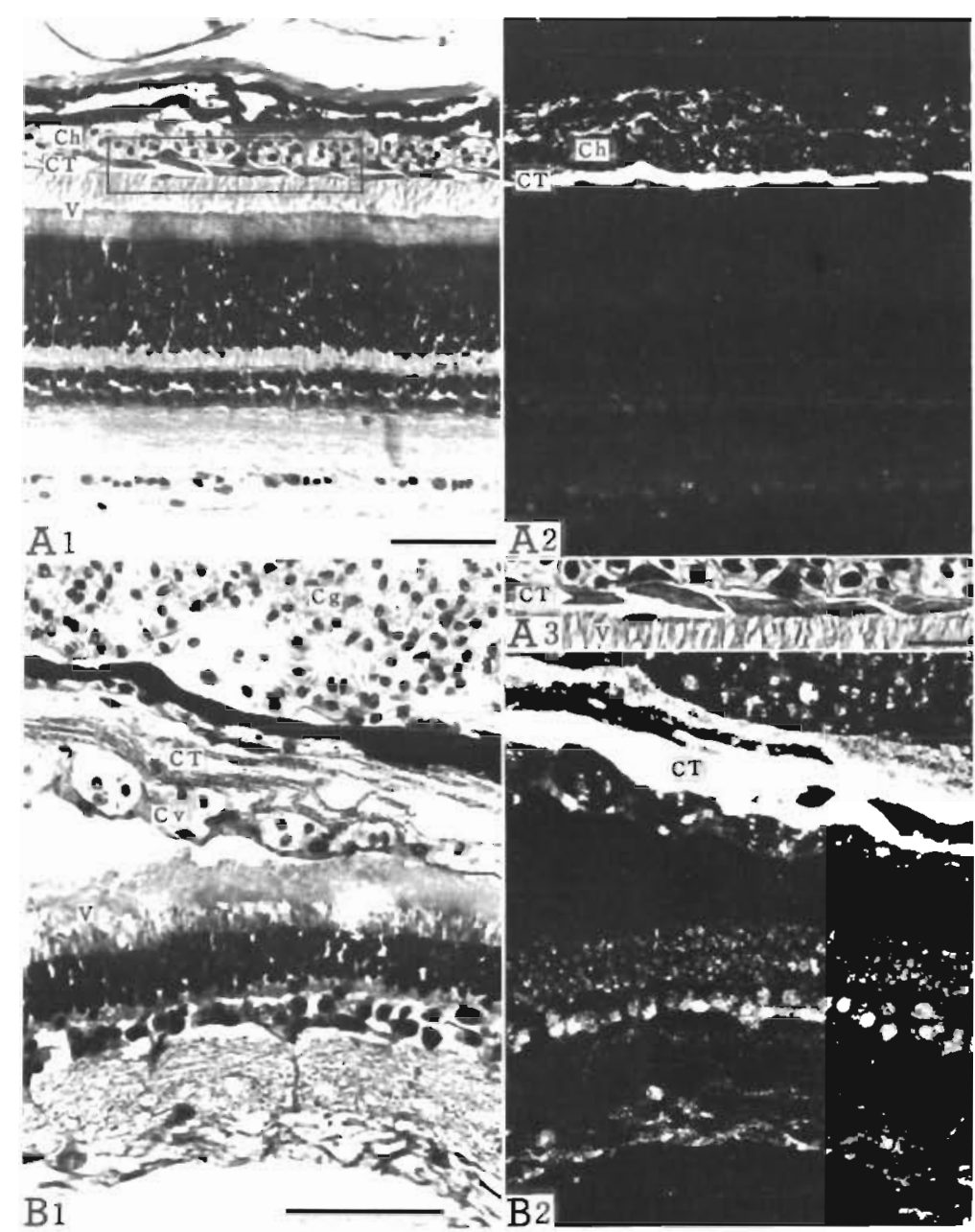

Fig. 6. Histological structures of choroidal tapetum. $A_{1}, A_{3}, B_{1}$ : light; $A_{2}, B_{2}$ : fluorescence microscopy. $A_{1}$, $A_{2}$ : Díaphus coeruleus; cross section of pure rod retina, bar $=50 \mu \mathrm{m} . \mathrm{A}_{3}$ : rectangular part of $\left(\mathrm{A}_{1}\right)$ showing positional detail of tapetal reflector $(C T)$, bar $=10 \mu \mathrm{m}$. B: Neoscopelus microchir; cross section of pure rod retina, bar $=50 \mu \mathrm{m}$. Ch: choriocapillaris; Cg: choroidal gland;

CT: choroidal tapetum; Cv: capillary vessel

sary in some families, e. g. the Elopidae, Notopteridae, and Evermannellidae. The tapetal material of Stizostedion (Percidae) which had long been believed to be guanine, was recently found to be reduced pteridine (Zyznar and Ali, 1975). Brauer (1908) presented the classic report on the eyes of many deep-sea fish, in which he referred both to 'Tapetum retinale' and 'Tapetum(s) chorioideale' (see his p. 230). But he used the term 'Tapetum' in a wider sense, including the reflecting layer (argentea) in the choroid and iris. He observed that some myctophids and Evermannella possess a guanine tapetum.

The habits and habitats of fishes which have a tapetum are usually linked to dimly lit environments, i. e. deep-sea, muddy streams and turbid water, or nocturnal activity. Indeed fishes with tapeta, reported in this paper, occur at moderate water depths e. g. species of Chlorophthalmus, Polymixia and Epigonus inhabit water between 200 and $300 \mathrm{~m}$; Beryx, between 100 and $800 \mathrm{~m}$; and Priacanthus and Pristigenys exhibit nocturnal activities and sometimes are found between 100 and $200 \mathrm{~m}$. These fishes have rod-dominant or pure rod retinas. Our findings support the general view that the tapeta exhibit morphological and ecological adaptations which increase visual sensitivity in environments where little light is available (Denton, 1970, 1971; Locket, 1970, 1971; Nicol, 1975; Zyznar, 1975).

\section{Possible Relationship Between the Retinal and Choroidal Tapeta}

\section{Functional Difference}

Retinal tapeta may be occlusible; the pigment epithelial cells always contain melanine granules which occlude the tapetal reflectors by shifting their position 


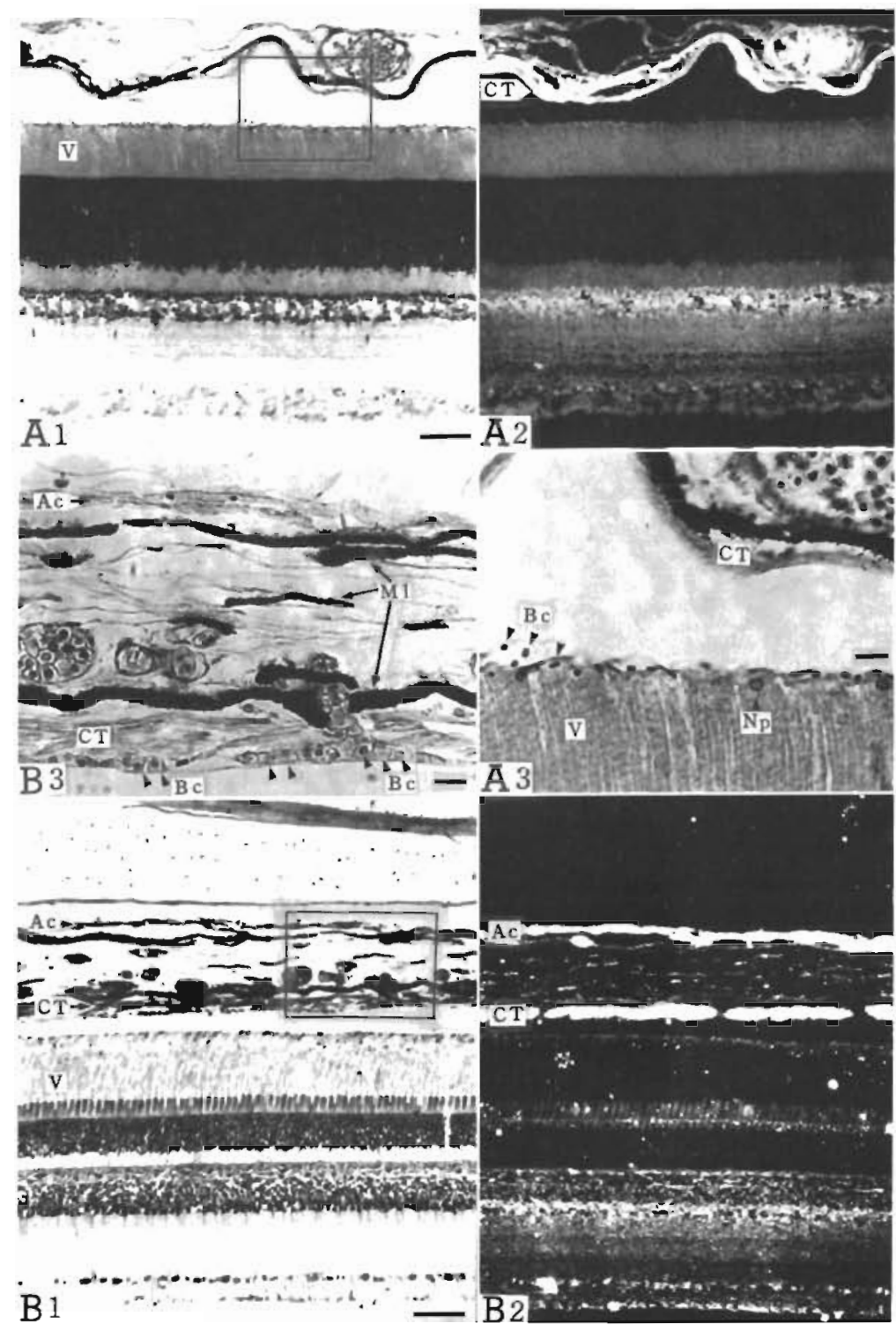

Fig. 7. Histological structures of choroidal tapetum. $A_{1}, A_{3}, B_{1}, B_{3}$ : light; $A_{2}, B_{2}$ : fluorescence microscopy. $A_{1}$, $A_{2}$ : Epigonus atherinoides; cross section of pure rod retina, bar $=50 \mu \mathrm{m}$. $\mathrm{A}_{3}$; rectangular part of $\left(\mathrm{A}_{1}\right)$, bar $=10 \mu \mathrm{m}$. $\mathrm{B}_{1}, \mathrm{~B}_{2}:$ Priacanthus boops; cross section of retina, bar $=50 \mu \mathrm{m}$. $\mathrm{B}_{3}$ : rectangular part of $\left(\mathrm{B}_{1}\right)$, bar $=10 \mu \mathrm{m}$. Ac: argentea of choroid; $\mathrm{Bc}$ : blood cell; $\mathrm{CT}$ : choroidal tapetum; Ml: melanophore layer of choroid; Np: nucleus of pigment epithelial cell; $V$; visual cell layer
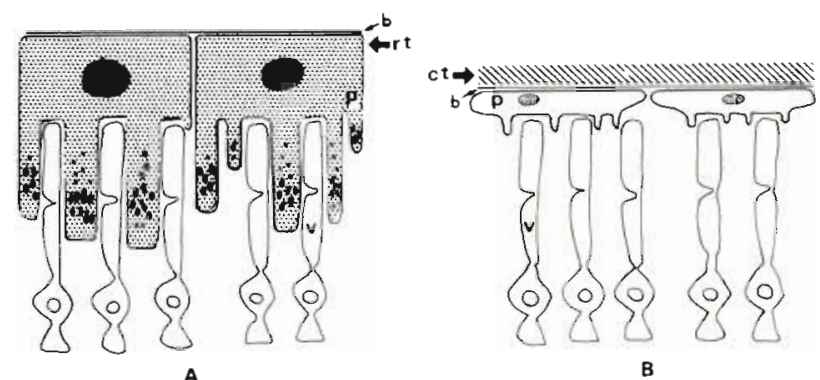

Fig. 8. Histological schemata of two different types of guanine tapetum in teleostei. A: retinal tapetum in pigment epithelial cells; it contains guanine reflectors. B: choroidal tapetum functioning as specular reflector in the vitread region of the choroid. b: Bruch's membrane; ct: choroidal tapetum; p: pigment epithelial cell; rt: retinal tapetum; v: visual cell
(Arnott et al., 1972, 1974; Nicol, 1975; Zyznar and Ali, 1975). On the other hand, choroidal tapeta reported in teleosts appear to be non-occlusible (O'Day and Fernandez, 1976); the teleostean choroidal tapeta do not have so-called 'migratory choroidal pigment cells' which cover the specular reflectors in the light as do those of some elasmobranchs, e. g. species of Squalus (Denton and Nicol, 1964). Table 6 suggests that the occurrence of occlusible retinal tapeta is associated with light environments with a wide range of light intensities ranging from deep-sea to muddy streams or turbid waters. On the other hand, the occurrence of non-occlusible choroidal tapeta seems to be strictly limited to constantly dim environments. 


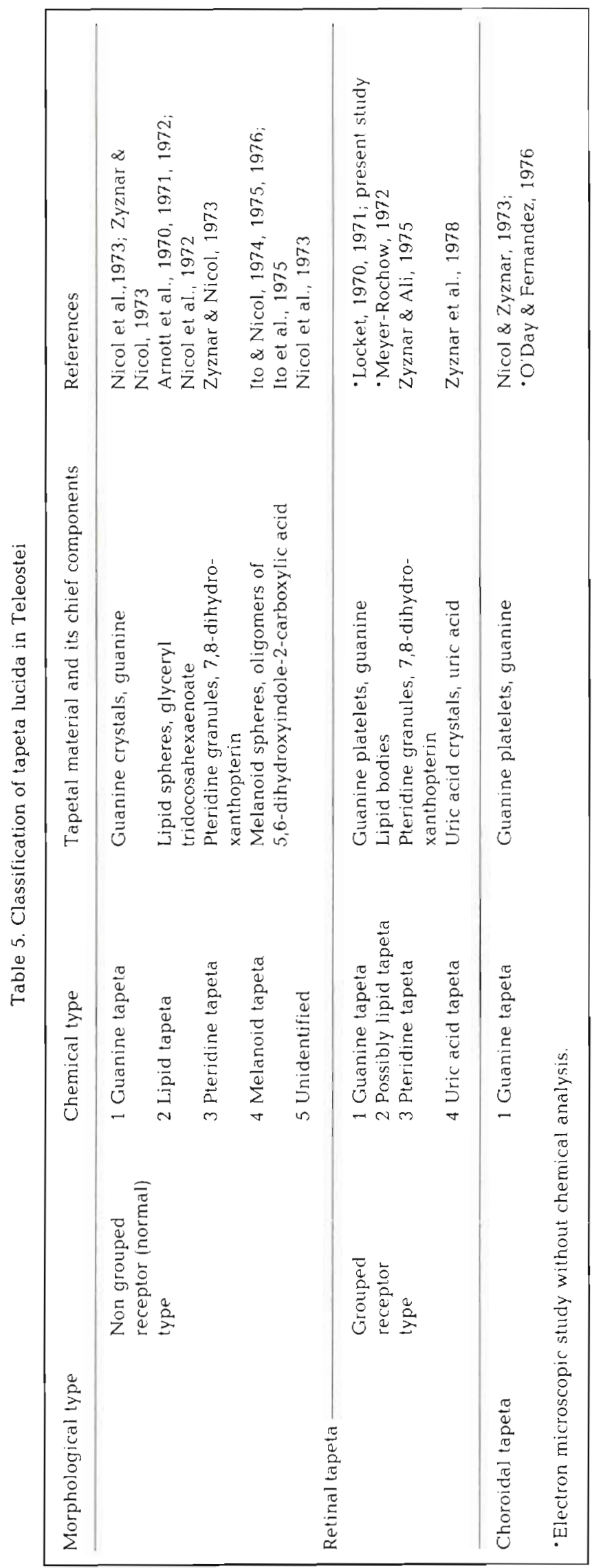

From these facts and present observations on structural differences between the two types of tapetum, it may be concluded that non-occlusible choroidal tapeta are morphological specializations for life in the constantly dim surroundings, e. g. deep-sea and strictly nocturnal habitats. On the other hand, occlusible retinal tapeta are specialized for life in dimly lit environments with diumal changes in light intensity.

\section{Chemical Diversity of Retinal Tapeta and Chemical Uniformity of Choroidal Tapeta}

A pigment epithelial cell of a retinal tapetum may contain both melanosomes and reflecting materials, i. e. guanine crystals, uric acid crystals, lipid spheres, pteridine granules, and melanoid spheres (Locket, 1971; Arnott et al., 1972; Ito et al., 1975; Zyznar and Ali, 1975; Fineran and Nicol, 1976, 1977, 1978; Frederiksen, 1976; Munk, 1977; Zyznar et al., 1978). Pigment cells containing two pigmentary organelles are also observed in some vertebrates (frog, salamander, snake), e. g. pterinosomes and melanosomes in erythrophores, melanosomes and reflecting platelets in melanophores, and so on (Taylor, 1971; Bagnara, 1972). From these observations, Bagnara (1972) concluded that 'all three pigmentary organelles, melanosomes, pterinosomes, and reflecting platelets may be derived from a common equipotential or pluripotential primordial organelle'. Indeed, transformation of iridophores (from tail skin of tadpoles) into melanophores in clonal culture was recently observed (Ide and Hama, 1976).

The findings mentioned above also suggest that pigment epithelial cells of the retina may be pluripotential or versatile in the production of pigment granules. Thus the chemical diversity of retinal tapeta may be explained by the pluripotential or versatility of a common primordial organelle in the pigment epthelial cells.

In the eyes of teleosts, the choroidal guanophores of neural crest origin (Kajishima, 1960, 1975), from the guanine-containing reflecting layer in the outer region of the choroid, i. e. the argentea. From present observations on structural (histological features and position) and chemical (mainly guanine) similarities between argentea and choroidal tapeta, I conclude that the reflector of choroidal tapeta may be a secondary derivative (branch) from the argentea. This assumption may explain the chemical uniformity of choroidal tapeta.

\section{Hypothetical Explanation of Tapetal Organization}

Observations on the structure of retinal and choroidal tapeta indicate that the pigment epithelial cells of 
Table 6. Guanine tapeta lucida in teleostei

\begin{tabular}{|c|c|c|c|c|}
\hline Family, species & Tapetum & Retina & Habit or habitat & Reference \\
\hline \multicolumn{5}{|l|}{ Elopidae (guanine?) } \\
\hline Elops saurus & $\mathrm{RT}+\mathrm{Gr}$ & $\mathrm{D}$ & Normally lit water & McEwan, 1938 \\
\hline Megalops atlanticus & $\mathrm{RT}+\mathrm{Gr}$ & $?$ & Normally lit water & McEwan, 1938 \\
\hline M. cyprinoides & $\mathrm{RT}+\mathrm{Gr}$ & $?$ & Normally lit water & McEwan, 1938 \\
\hline \multicolumn{5}{|l|}{ Engraulidae } \\
\hline Anchoa compressa & $\mathrm{RT}$ & $\mathrm{D}$ & Turbid & O'Connell, 1963 \\
\hline A. hepsettus & RT & $\mathrm{D}$ & Turbid & Nicol et al., 1973; Fineran \& Nicol, 1976, 1977 \\
\hline A. mitchilli & $\mathrm{RT}$ & $\mathrm{D}$ & Turbid & Zyznar \& Nicol, 1973; Fineran \& Nicol, 1976 \\
\hline Engraulis encrasicholus & $\mathrm{RT}$ & $\mathrm{D}$ & Turbid & McEwan, 1938 \\
\hline E. mordax & RT & $\mathrm{D}$ & Turbid & O'Connell, 1963 \\
\hline \multicolumn{5}{|l|}{ Notopteridae (possibly guanine) } \\
\hline Xenomystus nigri & $\mathrm{RT}+\mathrm{GI}$ & $\mathrm{D}$ & Nocturnal & Locket, 1971 ; Ito et al., 1975; Ali \& Anctil, 1976 \\
\hline Notopterus notopterus & $\mathrm{RT}+\mathrm{Gr}$ & $\mathrm{D}$ & Nocturnal & Ali \& Anctil, 1976 \\
\hline N. chilata & $\mathrm{RT}+\mathrm{Gr}(?)$ & $?$ & Nocturnal & Ito et al, 1975 \\
\hline \multicolumn{5}{|l|}{ Mormyridae } \\
\hline Petrocephalus stuhlmanni & $\mathrm{RT}+\mathrm{Gr}$ & $\mathrm{D}$ & Muddy stream & McEwan, 1938 \\
\hline P. brevipedunculatus & $\mathrm{RT}(?)+\mathrm{Gr}$ & $\mathrm{D}$ & Muddy stream & Engström, 1963 \\
\hline Gnathonemus macrolepidotus & $\mathrm{RT}+\mathrm{Gr}$ & $\mathrm{D}$ & Muddy stream & McEwan, 1938 \\
\hline Gnathonemus petersii & $\mathrm{RT}+\mathrm{Gr}$ & $\mathrm{D}$ & Muddy stream & Zyznar et al., 1978 \\
\hline Marcusenius longianalis & $\mathrm{RT}+\mathrm{Gr}$ & $\mathrm{D}$ & Muddy stream & Franz, 1920; Somiya, unpublished \\
\hline M. rudebeckii & $\mathrm{RT}(?)+\mathrm{Gr}$ & $\mathrm{D}$ & Muddy stream & Engström, 1963 \\
\hline \multicolumn{5}{|l|}{ Bathysauridae } \\
\hline Bathysaurus agassizi & $?$ & ? & Deep-sea & Zyznar et al., 1978 \\
\hline \multicolumn{5}{|l|}{ Chlorophthalmidae } \\
\hline Chlorophthalmus albatrossis & $\mathrm{RT}+\mathrm{Gr}$ & $\mathrm{D}$ & Deep-sea & Present study \\
\hline C. nigromarginatus & $\mathrm{RT}+\mathrm{Gr}$ & $\mathrm{D}$ & Deep-sea & Present study \\
\hline C. acutifrons & $\mathrm{RT}+\mathrm{Gr}$ & $\mathrm{D}$ & Deep-sea & Present study \\
\hline \multicolumn{5}{|l|}{ Myctophidae } \\
\hline Myctophum effulgens & $\mathrm{CT}$ & $\mathrm{R}$ & Deep-sea & Brauer, 1908 \\
\hline M. (= Diaphus) splendidus & $\mathrm{CT}$ & $\mathrm{R}$ & Deep-sea & Brauer, 1908 \\
\hline Diaphus coeruleus & $\mathrm{CT}$ & $\mathrm{R}$ & Deep-sea & Present study \\
\hline D. sagamiensis & $\mathrm{CT}$ & $\mathrm{R}$ & Deep-sea & Present study \\
\hline D. holti & $\mathrm{CT}$ & $\mathrm{R}$ & Deep-sea & Locket, 1977 \\
\hline Stenobrachius leucopsarus & $\mathrm{CT}$ & $\mathrm{R}$ & Deep-sea & O'Day \& Fernandez, 1976 \\
\hline Neoscopelus microchir & $\mathrm{CT}$ & $\mathrm{R}$ & Deep-sea & Present study \\
\hline \multicolumn{5}{|l|}{ Evermannellidae (guanine?) } \\
\hline Evermannella indica & $\mathrm{RT}+\mathrm{Gr}$ & $\mathrm{R}$ & Deep-sea & Brauer, 1908; Munk, 1966 \\
\hline E. $(=$ Coccorella $)$ atrata & $\mathrm{RT}+\mathrm{Gr}$ & $\mathrm{R}$ & Deep-sea & Brauer, 1908 \\
\hline \multicolumn{5}{|c|}{ Scopelarchidae (possibly guanine) } \\
\hline Scopelarchus güentheri & $\mathrm{RT}+\mathrm{Gr}$ & $\mathrm{R}$ & Deep-sea & Locket, 1971 \\
\hline S. sagax & $\mathrm{RT}+\mathrm{Gr}$ & $\mathrm{R}$ & Deep-sea & Locket, 1971 \\
\hline \multicolumn{5}{|l|}{ Notosudidae (possibly guanine) } \\
\hline Scopelosaurus lepidus & $\mathrm{RT}+\mathrm{Gr}$ & $\mathrm{D}$ & Deep-sea & Munk, 1977 \\
\hline S. hoedti & $\mathrm{RT}(?)+\mathrm{Gr}$ & $\mathrm{D}$ & Deep-Sea & Munk, 1975 \\
\hline Ahliesaurus berтyi & $\mathrm{RT}(?)+\mathrm{Gr}$ & $\mathrm{D}$ & Deep-sea & Munk, 1975 \\
\hline \multicolumn{5}{|l|}{ Omosudidae } \\
\hline Omosudis lowei & RT & $\mathrm{D}$ & Deep-sea & Frederiksen, 1976 \\
\hline \multicolumn{5}{|l|}{ Cyprinidae } \\
\hline Abramis brama & RT & $\mathrm{D}$ & Nocturnal & Exner \& Januschke, 1905; Zyznar et al., 1978 \\
\hline \multicolumn{5}{|l|}{ Bericidae } \\
\hline Beryx splendens & RT & $\mathrm{R}$ & Deep-sea & Present study \\
\hline B. decadactylus & RT & $\mathrm{R}$ & Deep-sea & Present study \\
\hline \multicolumn{5}{|l|}{ Polymixiidae } \\
\hline Polymixia japonica & $\mathrm{RT}+\mathrm{Gr}$ & $\mathrm{R}$ & Deep-sea & Present study \\
\hline P. berndti & $\mathrm{RT}+\mathrm{Gr}$ & $\mathrm{R}$ & Deep-sea & Present study \\
\hline \multicolumn{5}{|l|}{ Apogonidae } \\
\hline Epigonus atherinoides & $\mathrm{CT}$ & $\mathrm{R}$ & Deep-sea & Present study \\
\hline Priacanthidae & & & & \\
\hline Priacanthus arenatus & $\mathrm{CT}$ & $\mathrm{D}$ & Nocturnal & Nicol \& Zyznar, 1973 \\
\hline P. macracanthus & $\mathrm{CT}$ & $\mathrm{D}$ & Nocturnal & Present study \\
\hline P. hamrur & $\mathrm{CT}$ & $\mathrm{D}$ & Nocturnal & Present study \\
\hline P. boops & $\mathrm{CT}$ & $\mathrm{D}$ & Nocturnal & Present study \\
\hline Pristigenys niphonia & $\mathrm{CT}$ & $\mathrm{D}$ & Nocturnal & Present study \\
\hline
\end{tabular}




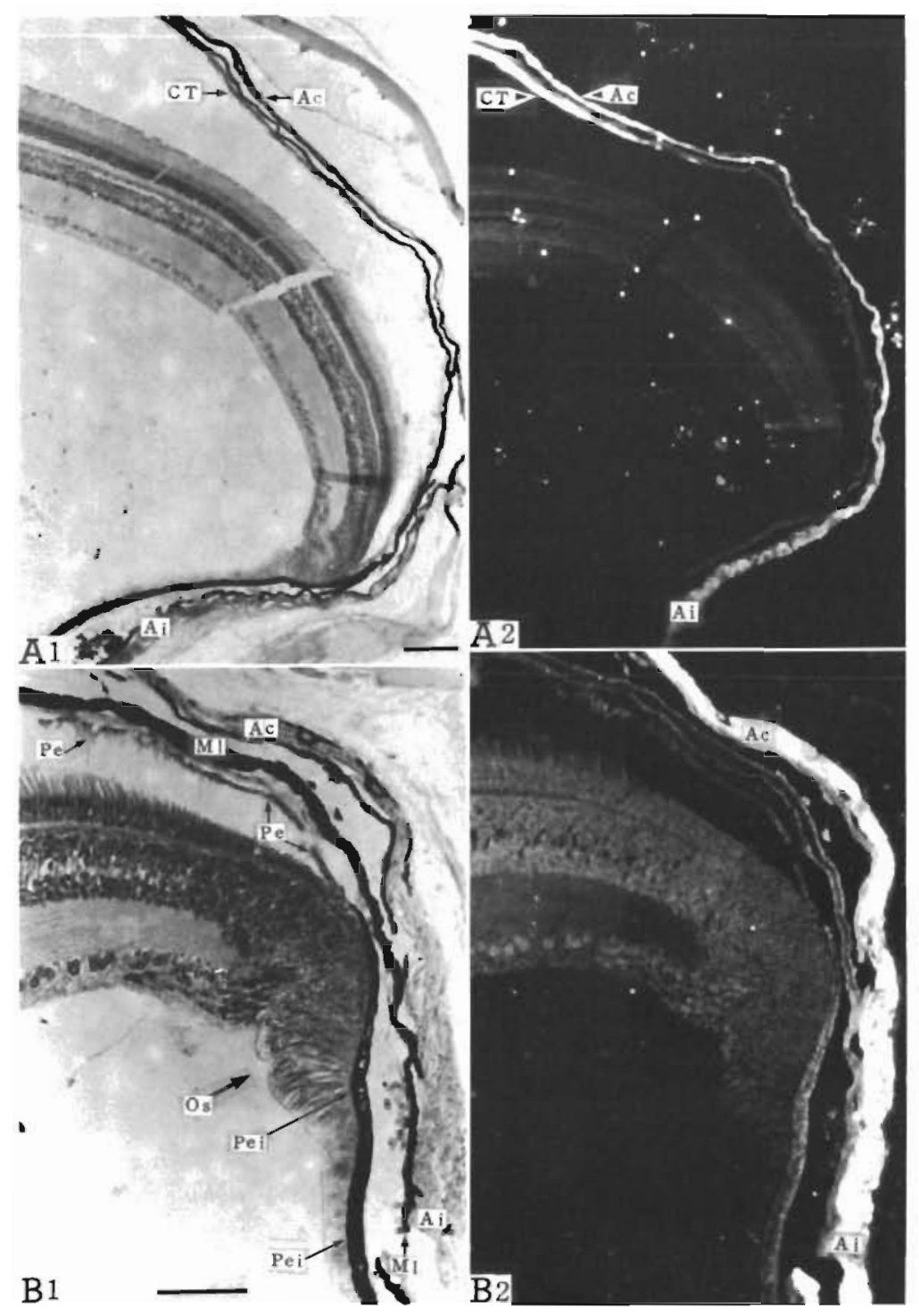

Fig. 9. Priacanthus boops. Histological structures of choroidal tapetum and argentea observed by light $\left(\mathrm{A}_{1}\right.$ and $\left.\mathrm{B}_{1}\right)$ and fluorescence microscopy $\left(\mathrm{A}_{2}\right.$ and $\left.\mathrm{B}_{2}\right)$. A: Cross section of retina showing positional relationship between choroidal tapetum (CT), argentea of choroid (Ac) and argentea of iris (Ai); bar $=100 \mu \mathrm{m}$. B: Cross section of retina showing position of pigment epithelium (Pe: Stratum pigmenti retinae) and pigment epithelium of iris (Pei: Stratum pigmenti iridis); bar $=50 \mu \mathrm{m}$. Ac: argentea of choroid; Ai: argentea of iris; MI: melanophore layer; Os: ora serrata

each tapetum are highly specific. While pigment epithelial cells of the retinal tapeta are characterized by containing reflecting or scattering materials (special cytodifferentiation), those associated with choroidal tapeta are characterized by lacking melanosomes.

Pigment epithelial cells of the retina usually have some important functions, e. g. supportive, nutritional, secretory. One important function of pigment epithelial cells in fish retinas is retinomoter response. In relation to this response it is generally known that the retinal pigment epithelium is well-developed in arythemic fishes capable of functioning in bright as well as dim environments (Ali, 1975), but remarkably reduced in nocturnal or deep-sea fishes. Hence it may be assumed that the development of pigment in the retinal pigment epithelial cells is primarily determined by environmental light conditions prevailing in the course of evolution. Indeed, if we compare the retinal pigment epithelial cells of various fishes inhabiting diumal to nocturnal or shallow to deep waters, we can easily detect serial stages in the development of pigment epithelial cells (Fig. 14). From this point of view, a hypothesis explaining two processes of tapetal organization, may be presented. This is schematically shown in Figure 14.

In the retinal tapeta of fishes living both in darkness 


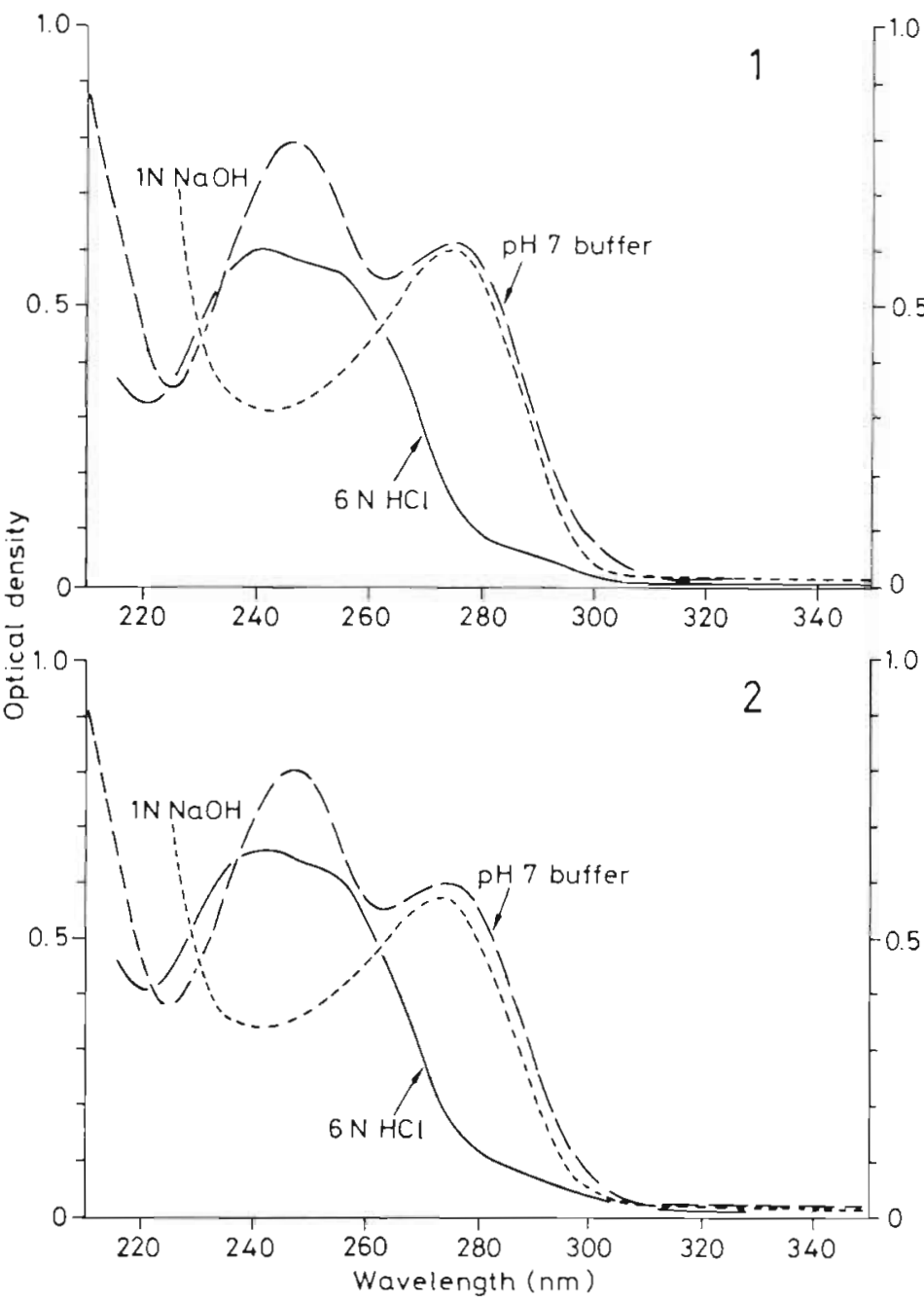

Fig. 10. Chlorophthalmus albatrossis. Ultraviolet absorption spectra of authentic guanine (1) and of tapetal extract (2) in three solvents: $1 \mathrm{~N} \mathrm{NaOH}, \mathrm{pH} 7$ buffer and $6 \mathrm{~N} \mathrm{HCl}$

and light, well-developed pigment epithelial cells could, in response to appropriate 'biological stimulation', differentiate into pigment cells containing both melanine and a tapetal reflector. In the above process any chemical substance produced in the pigment epithelial cell would serve as a tapetal material, so long as it has reflecting or scattering properties. Thus the chemical diversity of retinal tapeta may have resulted from a pluripotential organelle of the pigment epithelial cell.

The other process of tapetal organization (choroidal tapeta) in fishes living in a constantly dimly lit environment, the reduced non-pigmented retinal epithelial cell could not produce any pigment granules in accordance with Doll's 'Law of irreversibility' (Petronievics, 1919), but in response to 'biological stimulation' the tapetal reflector may have secondarily derived from the argentea. The argentea is composed of choroidal guanophores which always contain guanine. This may be why choroidal tapeta are chemically uniform.

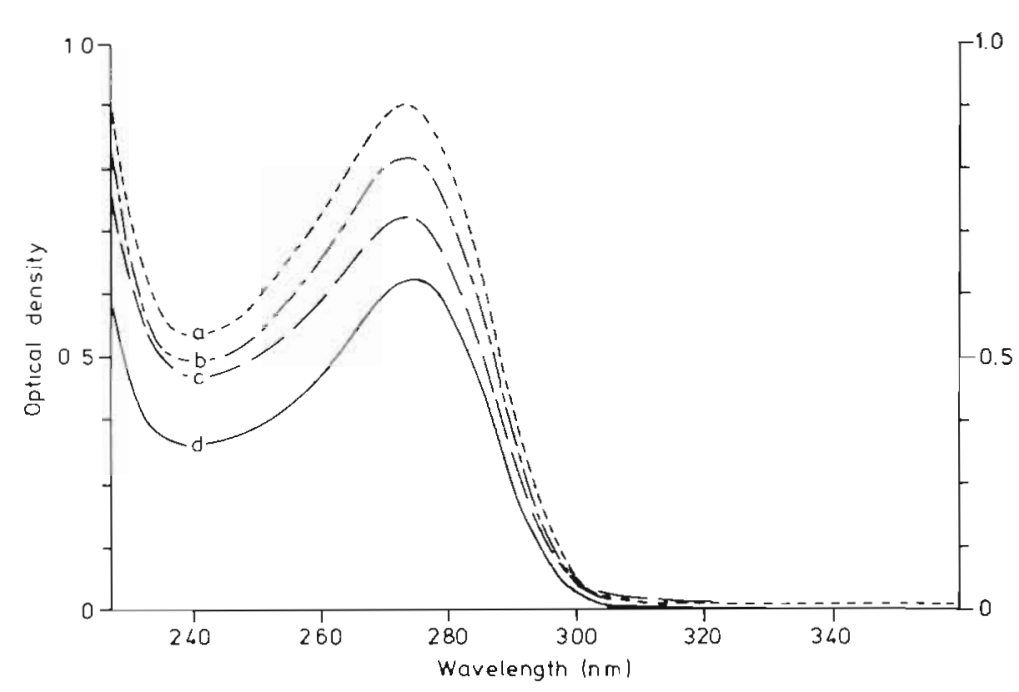

Fig. 11. Ultraviolet absorption spectra of the extract of retinal tapetum from Polymixia japonica (a), Chlorophthalmus albatrossis (b) and Beryx splendens (c), and authentic guanine (d) in $1 \mathrm{~N} \mathrm{NaOH}$

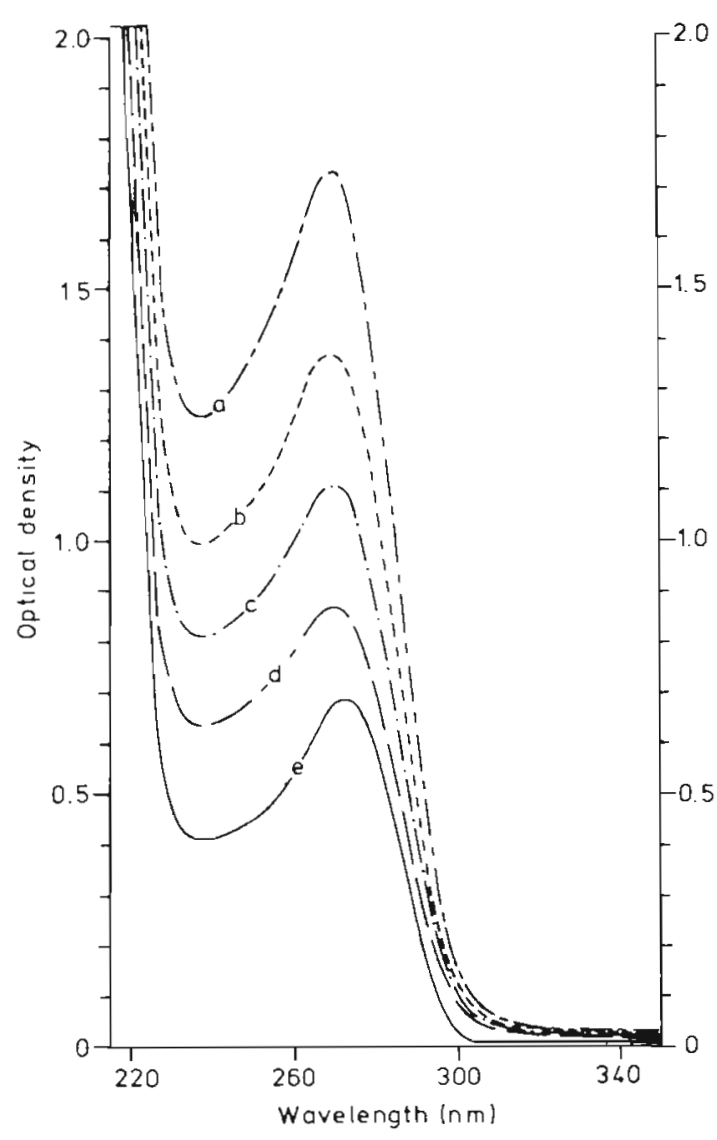

Fig. 12. Ultraviolet absorption spectra of the extract of choroidal tapetum from Priacanthus macracanthus (a), Priacanthus hamrur (b), Priacanthus boops (c), and Diaphus coerulus (d), and authentic guanine (e) in $0.1 \mathrm{~N} \mathrm{NaOH}$ 


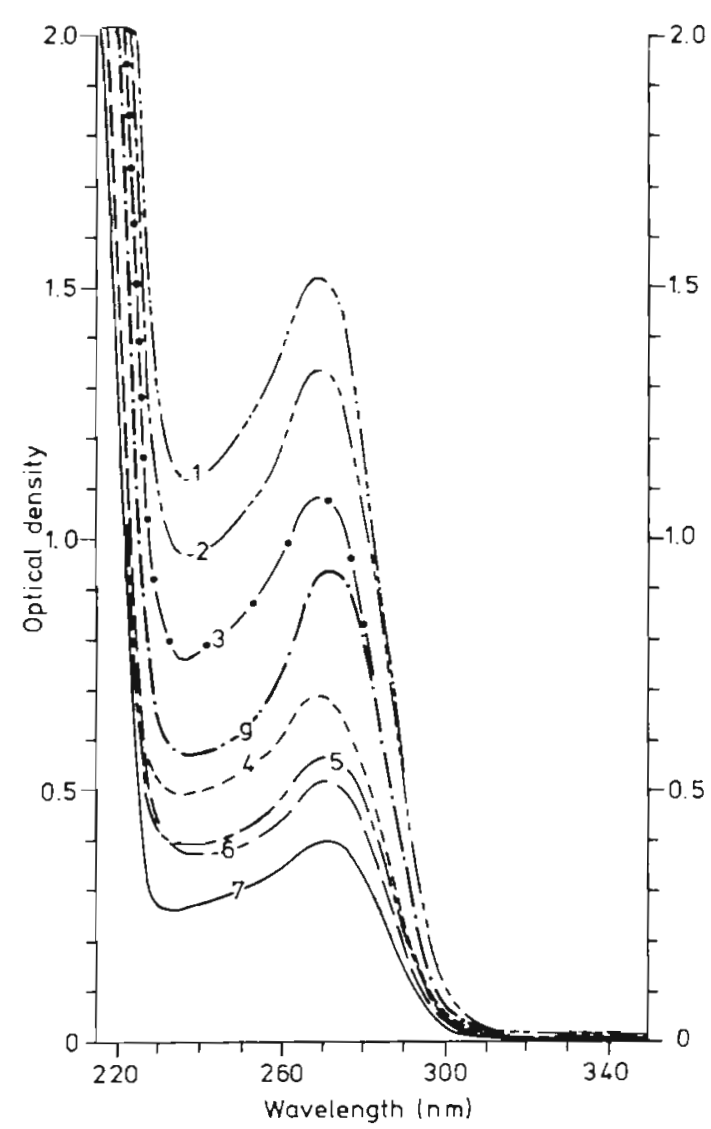

Fig. 13. Ultraviolet absorption spectra of authentic guanine $(\mathrm{g})$ and of the extract of argentea of choroid (1-6) and iris (7) in $0.1 \mathrm{~N} \mathrm{NaOH}$. 1: Diaphus coerulerus; 2: Priacanthus hamrur; 3 : Polymixia japonica; 4: Chlorophthalmus albatrossis; 5: Priacanthus macracanthus; 6: Priacanthus boops; (argentea of choroid); 7: Priacanthus boops (argentea of iris)

\section{'Biological Stimulation' of Tapetal Organization}

While definite information on 'biological stimulation' affecting tapetal organization is lacking, I have introduced this term in an effort to bring forth some concept regarding ecological and behavioral aspects in the life of deep-sea fishes. However, I discuss ecological aspects of 'biological stimulation' only in a few limited deep-sea fishes with tapeta.

The tapetum lucidum in fish eyes is considered one of the most specialized structures (morphological and chemical adaptation) for increasing photosensitivity in dimly lit environments. Deep-sea fishes with tapeta may depend on faint but important photo-signals (key stimuli), which are detectable only by the aid of an intra-ocular reflector. I assume that bioluminescence providing intra- or interspecific signals, may be one 'biological stimulation' affecting deep-sea fishes with tapeta. Indeed, most deep-sea fishes with guanine tapeta listed in Table 6 are luminous, e. g. Myctophum, Diaphus, Stenobrachius, Neoscopelus, Evernannella

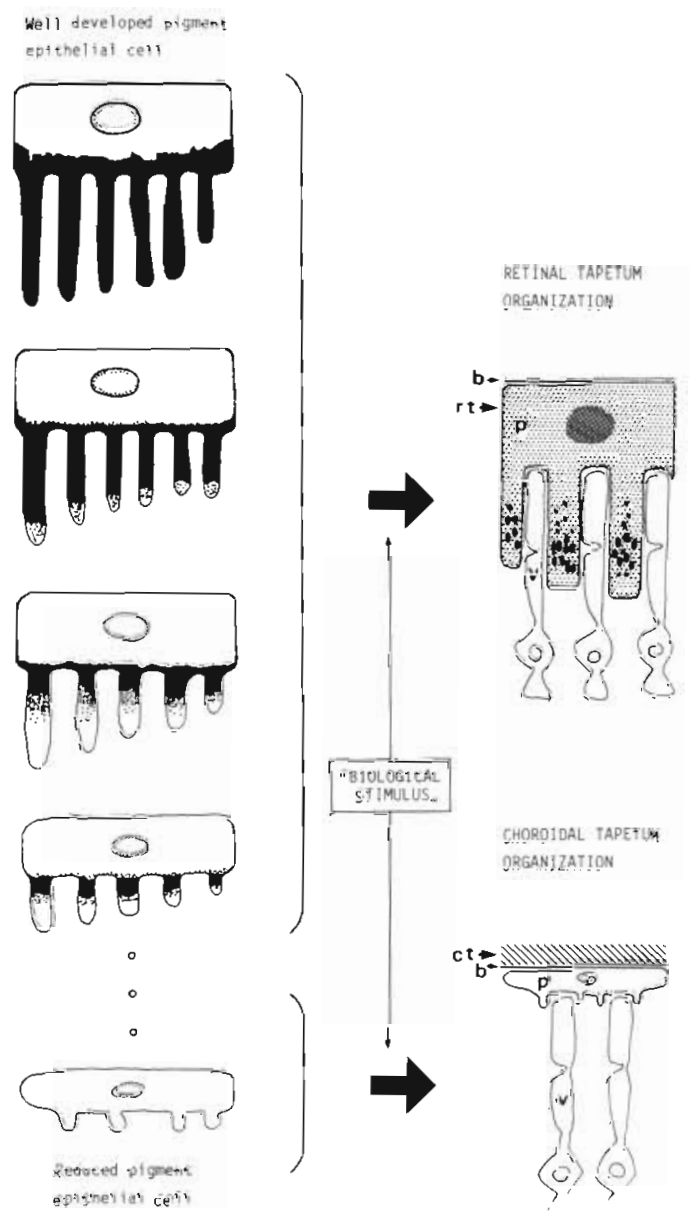

Fig. 14. Schematic and hypothetical representation of two processes of tapetal organization. One is retinal tapeturn organization characterized by special differentiation of pigment epithelial cells; the other, choroidal tapetum organization characterized by regeneration of pigment epithelial cells and secondary derivation from argentea in suprachoroid. b: Bruch's membrane; ct: choroidal tapetum; p: pigment epithelial cell; rt: retinal tapetum; v: visual cell

(Cocorella) and Epigonus (Herring and Morin, 1978). Recently, I have examined the luminous organ as a possible source of 'biological stimulation' (faint photosignal) in chlorophthalmid fishes and found a small, bacterial-operated light organ (Somiya, 1977). This finding indicates a possible relationship between tapeta (specialized eye characteristic) and dim bioluminescence. Life-maintaining responses operating through the detection of dim bioluminescence as key stimulus for intra- or interspecific communication may well have conditioned evolutional tapetal organization.

Acknowledgements. I wish to express my thanks to Professor T. Tamura for constant kindness; to Dr. T. Abe, Professor G. Eguchi, Mr. M. Hayashi, Professor T. Kajishima, Mrs. K. Koga, Professor R. Marumo, Mr. T. Somiya and Professor K. Suzuki for valuable assistance; and to the officers and crew of R. V. "Hakuho-Maru" of the Ocean Research Institute, University 
of Tokyo, for help in collecting samples. I am also indebted to Dr. Y. Haneda, Dr. K. Kawaguchi, Dr. H. Niwa, Dr. M. Oguri, Dr. M. Okiyama and Dr. T Tonoue for constant encouragement. The final version of this paper was worked out at The Plymouth Laboratory (U. K.), supported through kind comments by, and helpful discussions with, Dr. Q. Bone and Professor N. B. Marshall; I wish to express my thanks to them, as well as to Dr. J. B. Gilpin-Brown and other staff members of The Laboratory for generous support. My especial thanks go to Professor Eric Denton and Dr. Adam Locket for kind and unfailing discussions without which I could not have accomplished this paper

\section{LITERATURE CITED}

Ali, M. A. (1975). Retinomotor responses. In: Ali, M. A. (ed.) Vision in fishes. Plenum Press, New York and London. pp. 313-355

Ali, M. A., Anctil, M. (1976). Retinas of fishes, SpringerVerlag, Berlin

Arnott, H. J., Best, A. C. G., Ito, S., Nicol, J. A. C. (1974), Studies on the eyes of catfishes with special reference to the tapetum lucidum. Proc. R. Soc. (Ser. B) 186: 13-36

Arnott, H. J., Maciolek, N. J., Nicol, J. A. C. (1970). Retinal tapetum lucidum: A novel reflecting system in the eye of teleosts. Science, N. Y 169: 478-480

Arnott, H. J., Nicol, J. A. C., Querfeld, C. W. (1971). Reflecting spheres in the eyes of weakfishes (Sciaenidae). Nature, Lond. 233: $130-133$

Arnott, H. J., Nicol, J. A. C., Querfeld, C. W. (1972). Tapeta lucida in the eyes of the seatrout (Sciaenidae). Proc. R. Soc. (Ser. B) 180:247-271

Bagnara, J. T. (1972). Interrelationship of melanophores, iridophores, and xanthophores. In: Riley, V. (ed.) Pigmentation. Appleton-Centrury-Crofts, New-York, pp. 171-180

Bendich, A. (1957). Methods for characterization of nucleic acids by base composition. In: Colowick, S. P., Kaplan, N O. (eds) Methods in enzymology. Academic Press, New York. pp. 715-723.

Brauer, A. (1908). Die Tiefsee-Fischerei. 2. Anatomische Teil Wiss. Ergebn. dt. Tiefsee-Exped. 'Valdivia' 15 (2): 1-266

Brücke, E. (1845). Anatomische Untersuchungen über die sogenannten leuchtenden Augen bei den Wirbelthieren. Arch. Anat. Physiol. (Wiss. Med.) 1845: 387-406

Denton, E. J. (1970). On the organization of reflecting surfaces in some marine animals. Phil. Trans. R. Soc. (Ser. B) 258: 285-313

Denton, E. J. (1971). Reflectors in fishes. Sci. Am. 224: 65-72

Denton, E. J., Nicol, J. A. C. (1964). The chorioidal tapeta of some cartilarginous fishes (chondrichthyes). J. mar. biol. Ass. U. K. 44: $219-258$

Duke-Elder, S. (ed.) (1958). System of ophthalmology, Vol. 1, The eye in evolution, Henry Kimpton, London

Engström, K. (1963). Cone types and cone arrangements in teleost retinae. Acta zool. 44: 179-243

Exner, S., Januschke, H. (1905). Das Verhalten des Guanintapetums von Abramis brama gegen Licht und Dunkelheit. Sber. Akad. Wiss. Wien (math.-naturw. Klasse, Abt. 3) 114: 693-714

Fineran, B. A., Nicol, J. A. C. (1976). Novel cones in the retina of Anchovy (Anchoa). J. Ultrastruct. Res. 54: 296-303

Fineran, B. A., Nicol, J. A. C. (1977). Studies on the eyes of Anchovies Anchoa mitchilli and A. hepsetus (Engraulidae) with particular reference to the pigment epithelium. Phil. Trans. R. Soc. (Ser. B) 276: 321-350
Fineran, B. A., Nicol, J. A. C. (1978). Studies on the photoreceptors of Anchoa mitchilli and A. hepsetus (Engraulidae) with particular reference to the cones. Phil. Trans. R. Soc. (Ser. B) 283: 25-60

Franz, V. (1920). Zur mikroskopischen Anatomie der Mormyriden. Zool. J. 42: 91-148

Frederiksen, R. D. (1976). Retinal tapetum containing discrete reflectors and photoreceptors in the bathypelagic teleost Omosudis lowei. Vidensk. Meddr dansk naturh. Foren. 139: 109-146

Herring, P. J., Morin, J. G. (1978). Bioluminescence in fishes. In: Herring, P. J. (ed.) Bioluminescence in action. Academic Press, London. pp. 273-329

Ide, H., Hama, T. (1976). Transformation of amphibian iridophores into melanophores in clonal culture. Devl. Biol. 53: $297-302$

Ito, S., Nicol, J. A. C. (1974). Isolation of oligomers of 5, 6Dihydroxyindole-2-carboxylic acid from the eye of the catfish. Biochem. J. 143: 207-217

Ito, S., Nicol, J. A. C. (1975). Identification of decarboxylated S-adenosylmethionine in the tapetum lucidum of the catfish. Proc. R. Soc. (Ser. B) 190: 33-43

Ito, S., Nicol, J. A. C. (1976). Isolation of S-adenosyl-3-thiopropylamine from the eye of the sea catfish (Arius felis). Biochem. J. 153: 567-570

Ito, S., Thurston, E. L., Nicol, J. A. C. (1975). Melanoid tapeta lucida in teleost fishes. Proc. R. Soc. (Ser. B) 191: 369-385

Kajishima, T. (1960). Analysis of gene action in the transparent-scaled goldfish, Carassius auratus I. On the gene action in the disappearance of guanophores. Embryologia 5: $107-126$

Kajishima, T. (1975). In Vitro analysis of gene depression in goldfish choroidal melanophores. J. exp. Zool. 191. 121-126

Kühne, W., Sewall, H. (1880). Zur Physiologie des Sehepithels, insbesondere der Fische. Unters. Physiol. Inst. Heidelberg 3: 221-277

Kunz, Y. W., Wise, C. (1977). Regional differences of the argentea and sclera in the eye of Poecilia reticulata $\mathrm{P}$. (Teleostei: Cyprinodontidae). Zoomorphologie 87 : 203-215

Locket, N. A. (1970). Deep-sea fish retinas. Br med. Bull. 26: $107-111$

Locket, N. A. (1971). Retinal anatomy in some scopelarchid deep-sea fishes. Proc. R. Soc. (Ser. B) 178: 161-184

Locket, N. A. (1977). Adaptations to the deep-sea environment. In: Crescitelli, F. (ed.) Handbook of sensory physiology, Vol. VII/5, The visual system in vertebrates. Springer-Verlag, Berlin. pp. 67-192

McEwan, M. R. (1938). A comparison of the retina of the mormyrids with that of various other teleosts. Acta zool. 19: $427-465$

Meyer-Rochow, V. B. (1972). The larval eye of the deep-sea fish Cataetyx memorabilis (Teleostei, Ophididae). Z. Morph. Tiere 72: 331-340

Müller, H. (1856). Anatomisch-physiologische Untersuchungen über die Retina bei Menschen und Wirbelthieren. $Z$. wiss. Zool. 8: 1-122

Munk, O. (1966). Ocular anatomy of some deep-sea teleosts. Dana Rep. 70: 1-62

Munk, O. (1975). On the eyes of two foveate notosudid teleosts, Scopelosaurus hoedti and Ahliesaurus berryi. Vidensk. Meddr dansk naturh. Foren. 138: 87-125

Munk, O. (1977). The visual cells and retinal tapetum of the Foveate deep-sea fish Scopelosaurus lepidus (Teleostei). Zoomorphologie 87: 21-49

Muntz, W. R. A. (1972). Inert absorbing and reflecting pig- 
ments. In: Dartnall, H. J. A. (ed.) Handbook of Sensory Physiology, Vol. VII/1, Photochemistry of vision. SpringerVerlag, Berlin. pp. 529-565

Nicol, J. A. C. (1975). Studies on the eyes of fishes: Structure and ultrastructure. In: Ali, M. A. (ed.) Vision in fishes. Plenum Press, New York. pp. 579-607

Nicol, J. A. C., Arnott, H. J., Best, A. C. G. (1973). Tapeta lucida in bony fishes (Actionopterygii): a survery. Can. J. Zool. 51: 69-81

Nicol, J. A. C., Arnott, H. J., Mizuno, G. R. Ellison, E. C., Chipault, J. R. (1972). Occurrence of glyceryl tridocosahexaenoate in the eye of the sand trout Cynoscion arenarius. Lipids 7 : 171-177

Nicol, J. A. C., Van Baalen, C. (1968). Studies on the reflecting layers of fishes. Cont. mar. Sci. 13: 65-88

Nicol, J. A. C, Zyznar, E. S. (1973). The tapetum lucidum in the eye of the big-eye Priacanthus arenatus Cuvier. J. Fish Biol. 5: 519-522

Nicol, J. A. C., Zyznar, E. S., Thurston, E. L., Wang, R. T. (1975). The tapetum lucidum in the eyes of cusk-eels (Ophidiidae). Can. J. Zool. 53: 1063-1079

O Connell, C. P. (1963). The structure of the eye of Sardinops caerulea, Engraulis mordax, and four other pelagic marine teleosts. J. Morph. 113: 287-329

O'Day, W. T., Fernandez, H. R. (1976). Vision in the lanternfish Stenobrachius leucopsarus (Myctophidae). Mar Biol. 37: 187-195

Petronievics, B. (1919). Sur la loi de l'évolution irréversible. Sci. Prog. 13; 406-419

Pirie, A. (1966). The chemistry and structure of the tapetum lucidum in animals. In: Graham-Jones, O. (ed.) Aspects of comparative ophthalmology. Pergamon Press, Oxford. pp. $57-68$

Prince, J. H. (1956). Comparative anatomy of the eye, Charles C. Thomas, Springfield, Illinois
Rochon-Duvigneaud, A. (1943). Les Yeux et la Vision des Vertebres, Masson, Paris

Somiya, H. (1977). Bacterial bioluminescence in chlorophthalmid deep-sea fish: a possible interrelationship between the light organ and the eyes. Experientia 33: 906-909

Somiya, H., Tamura, T (1971). On the eyes of 'yellow lens' fish Chlorophthalmus albatrossis. Bull. Jap. Soc. scient. Fish. 37: 840-84.5

Tamura, T (1957). A study of visual perception in fish, especially on resolving power and accommodation. Bull. Jap. Soc. scient. Fish. 22: 536-557

Taylor, J. D. (1971). The presence of reflecting platelets in integumental melanophores of the frog, Hyla arenicolor. $J$. Ultrastruct. Res. 35: 532-540

Walker, E. P. (1939). Eyes that shine at night. A. Rep. Smithson. Instn 1938: 349-360

Walls, G. L. (1942). The vertebrate eye and its adaptive radiation, The Cranbrook Institute of Science, Bloomfield Hill, Michigan

Zyznar, E. S. (1975). Theoretical considerations about tapeta lucida. In: Ali, M. A. (ed.) Vision in fishes. Plenum Press, New York and London. pp. 305-312

Zyznar, E., Ali, M. A. (1975). An interpretative study of the organization of the visual cells and tapetum lucidum of Stizostedion. Can. J. Zool. 53: 180-196

Zyznar, E. S., Cross, F. B., Nicol, J. A. C. (1978). Uric acid in the tapetum lucidum of mooneyes Hiodon (Hiodontidae Teleostei). Proc. R. Soc. (Ser. B) 201: 1-6

Zyznar, E. S., Nicol, J. A. C. (1973). Reflecting materials in the eyes of three teleosts, Orthopristes chrysopterus, Dorosoma cepedianum and Anchoa mitchilli. Proc. R. Soc. (Ser. B) $184: 15-27$

This paper was presented by Professor M. Anraku; it was accepted for printing on October 12, 1979. 